\title{
Emerging organic contaminants in groundwater: A review of sources, fate and occurrence
}

Lapworth D.J ${ }^{1 *}$, Baran $N^{2}$, Stuart, M.E ${ }^{1}$, Ward R.S ${ }^{1}$

${ }^{1}$ British Geological Survey, Mclean Building, Wallingford, Oxfordshire, OX10 8BB, UK

${ }^{2}$ Bureau de Recherches Géologiques et Minières, 3 Avenue Claude Guillemin, BP 6009, 45060 Orléans Cedex 2, France

*Corresponding author: djla@bgs.ac.uk

\begin{abstract}
Emerging organic contaminants (EOCs) detected in groundwater may have adverse effects on human health and aquatic ecosystems. This paper reviews the existing occurrence data in groundwater for a range of EOCs including pharmaceutical, personal care, 'life-style' and selected industrial compounds. The main sources and pathways for organic EOCs in groundwater are reviewed, with occurrence data for EOCs in groundwater included from both targeted studies and broad reconnaissance surveys. Nanogram-microgram per litre concentrations are present in groundwater for a large range of EOCs as well as metabolites and transformation products and under certain conditions may pose a threat to freshwater bodies for decades due to relatively long groundwater residence times. In the coming decades, more of these EOCs are likely to have drinking water standards, environmental quality standards and/or groundwater threshold values defined, and therefore a better understanding of the spatial and temporal variation remains a priority.
\end{abstract}

Keywords: emerging contaminants; review; groundwater; pharmaceuticals; occurrence 
Capsule: A large range of emerging organic contaminants are now being detected in groundwater as a result of recent and historical anthropogenic activities.

\section{Introduction}

A diverse array of synthetic organic compounds are used by society in vast quantities for a range of purposes including the production and preservation of food, industrial manufacturing processes, as well as for human and animal healthcare. In the last few decades there has been a growing interest in the occurrence of these, so called, 'micro-organic contaminants' in the terrestrial and aquatic environment, their environmental fate and their potential toxicity (Stan and Linkerhagner, 1992; Stan et al., 1994; Halling-Sørensen et al., 1998;Daughton and Ternes, 1999; Schwarzenbach et al., 2006; Kümmerer, 2009). The contamination of groundwater resources by micro-organics is a growing concern and relatively poorly understood compared to other freshwater resources. Groundwater provides the most reliable perennial source of freshwater on Earth. It maintains flows and levels in rivers and lakes, is essential for the health of groundwater-dependant ecosystems, and in many parts of the world is the most important source of drinking water.

Of particular concern are 'emerging organic contaminants' (EOCs). This term is used to cover not only newly developed compounds but also compounds newly discovered in the environment — often due to analytical developments (Lindsey et al., 2001; Petrovic and Barceló, 2006; Richardson and Ternes, 2011) and compounds that have only recently been categorised as contaminants. EOCs include a wide array of different compounds (as well as metabolites and transformation products- collectively referred to here as degradates) including; pharmaceuticals and personal care products (PPCPs), pesticides, veterinary products, industrial compounds/by-products, food additives as well as engineered nanomaterials. Because of the vast array of possible compounds, many studies have selected EOCs 
according to priority lists established taking into account consumption, predicted environmental concentrations as well as ecotoxicological, pharmacological and physicochemical data (e.g. Hilton et al., 2003; Huschek et al., 2004; Fent et al., 2006; Crane et al., 2006; Besse and Garric, 2008; Celiz et al., 2009).

To date the occurrence of EOCs has been much better characterised in wastewater and surface water environments compared to groundwater (see Pal et al., 2010 and references therein). Wastewaters are the main sources of EOCs in the environment and surface waters contain the greatest loads of EOCs. Wastewaters and surface waters are also generally thought to contain a much greater diversity of compounds compared to groundwater, although this may be simply a function of the capability of various analytical methods and the limited number of groundwater studies rather than actual environmental occurrence.

It is now established that these compounds enter the environment from a number of sources and pathways: wastewater effluents from municipal treatment plants (Heberer et al., 1997, 1998, 2004; Kolpin et al., 2002); septic tanks (Verstraeten et al., 2005; Swartz et al., 2006); hospital effluents (Kümmerer, 2001); livestock activities including waste lagoons and manure application to soil (Shore and Shemesh, 2003; Watanabe et al., 2010); subsurface storage of household and industrial waste (e.g. Eckel et al., 1993; Holm et al., 1995), as well as indirectly through the process of groundwater-surface water (GW-SW) exchange (Buerge et al., 2009).

Recent reviews have covered the occurrence of EOCs in surface waters used for public water supply (Houtman, 2010), the sources, occurrence and fate of 'emerging organic contaminants' (EOCs) in surface water sources (Pal et al., 2010), and trace pollutants and EOCs in fresh water sources (Murray et al., 2010). Díaz-Cruz and Barceló (2008) recently reviewed priority and emerging organic micro-pollutants in the different source waters used for artificial aquifer recharge purposes and Einsiedl et al. (2010) assessed the occurrence and transport of 
pharmaceuticals in karst groundwater systems affected by domestic waste water treatment. In a review by Jones et al. (2005), pharmaceuticals (11 EOCs) were reported in drinking waters from Germany, UK, Italy, Canada and USA. While individual compounds were generally found in concentrations that are considered too low to cause acute effects (i.e. typically $<100$ $\mathrm{ng} / \mathrm{L}$ ), it is clear that the toxic effects due to long-term exposure to a combination of low concentrations of range of emerging contaminants are not well understood. To date, review articles concerning freshwater EOC occurrence have focused on surface water resources, or only drawn on groundwater data from a handful of case studies (e.g. Caliman and Gavrilescu, 2009; Murray et al., 2010; Pal et al., 2010; Houtman, 2010). There has not been a systematic review of published studies focusing on the occurrence of EOCs in groundwater.

This paper reviews the occurrence of a range of EOCs (as well as their degradates) in groundwater including: pharmaceuticals; personal care compounds; veterinary medicines; 'life-style compounds'; x-ray contrasting agents; steroids; surfactants; plasticisers; metabolic regulators; preservatives; food additives, as well as a large range of other waste water related compounds and focuses on EOCs that are under review or do not currently have drinking water standards in Europe. It focuses on the main sources, pathways and fate of EOCs in groundwater, and evaluates the occurrence of EOCs in groundwater including data from targeting studies and broad reconnaissance surveys from 14 countries across Europe, the Middle East, North America and Asia. The vast majority (c.75\%) of articles included in this review were published after 2001. Important processes that control the fate of EOCs in the subsurface are discussed, and the use of EOCs as tracers in groundwater studies is assessed, as well as their potential impact on water resources. Particular attention is paid to the occurrence of known and potential endocrine disrupting substances (EDS) in groundwater. Current gaps in our understanding regarding EOCs in groundwater are highlighted as well as possible areas for future research. 
Agricultural pesticides and their degradates have not been included in this review; the environmental occurrence of this group of organic contaminants is better characterised and reviewed compared with many other groups of EOCs and are better regulated with respect to drinking water standards in many countries (Leistra and Boesten, 1989; Ritter, 1990; Kolpin et al., 1998; Murray et al., 2010; Stuart et al., 2011).

\section{Regulation of EOCs in groundwater}

Monitoring of anthropogenic micro-organic pollutants in river basins is required within the framework of various national regulations (e.g. EC, 2006; USEPA, 2006) with the overall aim of protecting and improving the quality of water resources. It would be fair to say that the spatial and temporal variability of the majority of EOCs in the environment is still poorly understood, and is a topic of growing interest from both research and regulatory perspectives. The absence of regulatory drinking water, environmental quality standards or groundwater threshold values for many micro-organic contaminants does not mean that they do not pose a potential threat to human health or aquatic ecosystems; rather, in many cases that their toxicity and environmental occurrence are as yet poorly understood. The number of compounds that are regulated through drinking water standards and/or environmental quality standards is therefore likely to grow in the coming decades.

In Europe the EU Water Framework Directive (WFD - 2000/60/EC) and its daughter Groundwater Directive (2006/118/EC) establish environmental objectives for protecting groundwater and the water bodies and ecosystems dependent on groundwater. As part of achieving these objectives groundwater bodies have to be at "good status". In assessing status, threshold values (standards) have to be established for pollutants that put the groundwater body at risk of failing to achieve any of its environmental objectives. Whilst for many chemical pollutants there is sufficient knowledge to establish threshold values, in the case of 
many EOCs the lack of knowledge on toxicity, impact, behaviour and limited monitoring data mean that threshold values cannot yet be set. However, in the future, if EOCs are found to lead to the risk of pollution of groundwater and have the potential to compromise environmental objectives then standards (threshold values) will be required. These will also have to be reported to the European Commission. The EU Drinking Water Directive (EC, 2006) also does not currently include standards for EOCs and is unlikely to change in the near future as a recent proposed review has been postponed.

The same situation occurs elsewhere in the world. Regulatory frameworks exists to manage the potential sources of pollution and require monitoring of a number of 'priority' organic contaminants in the aquatic environment (e.g. pesticides and degradates, VOCs, chlorinated solvents, water disinfection by-products and PAH, e.g. Teijon et al., 2010). However, there are a huge number of contaminants (largely organic compounds) that are not subject to the same degree of regulation at present (for the same reasons as above). The US Environment Protection Agency published a new contaminant candidate list (CCL-3) in 2009 which included 3 pharmaceuticals (erythromycin, 17R-ethinylestradiol (EE2), and nitroglycerin) as well as perfluorooctanoic acid (PFOA), perfluorooctane sulfonate (PFOS) and eight hormones: 17R-estradiol, 17 $\beta$-estradiol, equilenin, equilin, estriol, estrone, mestranol, and norethindrone (Richardson and Ternes, 2011). It was recently reported (August 2011) that the European Commission aims to table draft limits for 16 new substances limits under the WFD including the following EOCs: anti-inflammatory drugs ibuprofen and diclofenac; the synthetic contraceptive ethinylestradiol; naturally occurring oestrogen oestradiol; and PFOS (ENDS, 2011).

By definition EOCs have not been widely studied compared to other anthropogenic contaminants, and there is a paucity of information on their occurrence and fate in the aquatic environment. In response to this there has been a an effort in many countries/regions to study 
the sources and occurrence of EOCs in the environment and prioritise key compounds which pose a potential ecological threat. For example in the USA there have been a series of programmes including those funded by the USGS, NOAA, USEPA and the Department of Defence. There has been a parallel set of research programmes funded by the European Union (e.g. , as well as examples of national reconnaissance studies (e.g. Barnes et al., 2008, NAQUA, 2009, Stuart et al., 2011).

\section{Sources, pathways and fate of EOCs in the subsurface}

This section synthesises available data for EOCs in groundwater using the common sourcepathway-receptor framework. Sources of EOCs in the environment that may eventually impact groundwater can be divided into i) point-sources and ii) diffuse sources of pollution. The main sources of EOC pollution in the environment are summarised in this section, including analysis of key sources, pathways and fate of EOC in the subsurface that can lead to groundwater pollution. This is summarised in Figure 1, highlighting those sources of pollution and pathways which are thought to have the greatest impact on groundwater resources.

\subsection{Sources and pathways for groundwater pollution by EOCs}

Point-source pollution originates from discrete locations whose inputs into aquatic systems can often be defined in a spatially discrete manner. The spatial extent or plume of pollution is therefore generally more constrained. Important examples include industrial effluents (e.g. manufacturing plants, hospitals, food processing plants), municipal sewage treatment plants and combined sewage-storm-water overflows, resource extraction (mining), waste disposal sites (landfill sites, industrial impoundments, farm waste lagoons) and buried septic tanks. Diffuse pollution, in contrast, originates from poorly defined, diffuse sources that typically occur over broad geographical scales. Examples of diffuse source pollution include agricultural runoff from bio-solids and manure sources, storm-water and urban runoff, leakage 
from reticulated urban sewerage systems and diffuse aerial deposition (e.g. Leister and Baker 1994; Knoth et al., 2003; Schmid et al., 2004; Terry et al., 2008; Vulliet et al., 2008; Nakada et al., 2008; Buerge et al., 2011). These sources of pollution can be characterised as: i) covering larger geographical scales, ii) having generally lower environmental loading compared to point sources, iii) having higher potential for natural attenuation in the soil and subsurface, iv) and are poorly defined with less direct/obvious links back to the 'polluter', as such they continue to be a real challenge to monitor, regulate and assess their impact on groundwater resources.

To date the vast majority of published studies have focussed on groundwater contamination by EOCs from point sources (e.g. Heberer, 2002; Rabiet et al., 2006; Barnes et al., 2004; Drewes et al., 2002; Watanabe et al., 2008; Maeng et al., 2010, 2011). This is likely due to the combination of factors; i) point source pollution usually results in higher EOC loading to a particular environmental receptor (surface water or groundwater body or aquatic species), this also means that they are easier to detect in the environment, ii) engineered solutions to point source pollution are perhaps more straightforward, are seen to deliver the greatest environmental benefit, and as such attract the greatest funding, iii) there is a stronger historical legacy of regulatory control on point source pollution, and the connection between the pollution and the polluter is more easy to define, iv) and as such is easier to conceptualise, monitor and predict compared to diffuse pollution.

For many EOCs there may be multiple pathways to groundwater and associated receptors (see Figure 1), and difficulties in understanding these processes are compounded by paucity of information compared to surface water. In certain situations, (e.g artificial recharge) and surface-groundwater exchange the source term and pathways are more clearly defined (Schmidt et al., 2003; Díaz-Cruz and Barceló, 2008) and can be traced in the environment. 
Figure 2 summarises visually (box-plot) the maximum EOC concentration in groundwater derived from a synthesis of 69 published studies (see Table S1 for further details). The data are divided on the basis of major sources; agricultural waste (from waste lagoons and biosolids), landfill, septic tanks, waste water (industrial and municipal). Landfill sources have the highest median value for all EOCs, the other sources have comparable median values. Waste water contaminated groundwater has the largest number of compounds and results (see Figure 2). Agricultural waste contaminated groundwater has both the smallest number of compounds and number of samples overall. While there are several compounds (carbamazepine, sulfamethoxazole, ibuprofen, caffeine and nonylphenol (NP)) that are found in groundwaters impacted by three different source types, no EOC was reported in all four source types. This reflects the fact that to date waste water sources have been better characterised than other sources. Some contaminants are more source specific (e.g. contrasting agents from hospitals and veterinary pharmaceuticals) and as such are easier to trace in the environment compared to contaminants with multiple potential sources (e.g. caffeine). While for many pharmaceuticals there are multiple sources in the environment globally, it is still possible to elucidate source terms on a local or sub-regional scale (e.g. Clara et al., 2004; Buerge et al., 2009, 2011). The following sections critically review pollution of groundwater resources by EOCs from key point and diffuse sources.

\subsubsection{Point sources}

Waste water sources are considered one of the most important point sources of EOCs in the aquatic environment (Glassmeyer et al., 2005). A large number of studies have investigated the fate of EOCs in groundwater following infiltration of waste waters (sewage and industrial) as well as contaminated surface water sources, and to date provides the largest body of 
research regarding the sources and fate of EOCs in the subsurface. The work has been carried out in many countries including Germany, USA, UK, Denmark, Spain, Italy, Austria, Israel and France (e.g. Adler et al., 2001; Heberer et al., 1997, 2004; Grünheid et al., 2005, 2000; Sacher et al., 2001; Heberer and Adam, 2004; Drewes et al., 2003; Mansell and Drewes, 2004; Snyder et al., 2004; Katz et al., 2009; Rabiet et al., 2006; Clara et al., 2004; Kreuzinger et al., 2004; Pecoranio et al., 2008; Gasser et al., 2010). A review of the sources and fate of organic wastewater contaminants (OWCs) following artificial recharge/infiltration of a range of waste water sources to the subsurface was recently carried out by Díaz-Cruz and Barceló (2008). This review showed that artificial recharge continues to be a very important potential source of EOCs in groundwater, particularly when groundwater residence times are short, and poses a threat to adjacent groundwater bodies as well as surface water resources. This source is clearly a major input of EOCs into the environment globally, especially in regions where waste water treatment is poorly regulated and rudimentary or non-existent. However, even where treatment systems are advanced removal is still incomplete, and as such these sources can still be a major input in the environment. The suite of molecules potentially released into the environment is large depending the origin of the water treated. A recent example which has illustrated the potential for molecules to by-pass sophisticated treatment processes has been the widespread occurrence of metaldehyde (active ingredient of slug pellets) in treated drinking water sources (Water UK 2011). Hospital waste water forms an important source for a range of specific EOCs, including x-ray contrast media, and certain therapeutic drugs (Putschew et al., 2000; Ternes and Hirsch, 2000; Sacher et al., 2001, Schulz et al., 2008). Landfill sites have also been shown to be important sources for EOC contaminants in groundwater for the many years and have a continued legacy as sources of groundwater contamination today due in part to historical landfill practices regarding landfill construction, waste management and in some cases poor choices regarding landfill location. This is in stark 
contrast with modern landfill design and management practices across parts of Europe and North America. However, in many developing countries there is presently limited effective regulation regarding groundwater protection from landfill sources. This, combined with the large increase in use of pharmaceuticals in recent years as well as the increased abstraction for domestic use in many developing regions suggests that this may be an important source of groundwater (drinking water) contamination for many years to come.

Many early studies reported a wide range of pharmaceuticals in groundwater down gradient of landfills receiving domestic and industrial waste (e.g. Eckel et al., 1993; Holm et al., 1995; Ahel et al., 1998; Ahel and Jelicic 2000). Two recent studies (Barnes et al., 2004 and Buszka et al., 2009) show the persistence of EOCs in groundwater down gradient of landfills detecting a range of industrial compounds (detergents, antioxidants, fire retardants, plasticisers) as well as PPCPs (antibiotics, anti-inflammatories, barbituates), caffeine and the nicotine metabolite cotinine. In many of these studies EOCs have been detected in significant concentrations between $10-10^{4} \mathrm{ng} / \mathrm{L}$.

Septic tanks remain important sources of groundwater pollution by EOCs, particularly where groundwater tables are shallow and aquifers have high transmissivity. It is very difficult to effectively monitor and regulate contamination from septic tanks, even in North America and Europe, due to the huge number of these point sources, and widespread use in rural settings. A detailed study carried out in Canada (Carrara et al., 2007) showed septic tank samples contained elevated concentrations of several pharmaceutical compounds. As a result, when they leak they may be an important source of EOC contamination of groundwaters. Large differences among groundwater samples down-gradient of the septic tanks were observed in both the number of detections and the concentrations of the pharmaceutical compounds. Of the compounds analysed pharmaceuticals, ibuprofen, gemfibrozil, and naproxen were observed. Several case studies in the USA have reported a range of EOCs in groundwater 
impacted by septic tanks (e.g. Verstraeten et al., 2005; Swartz et al., 2006; Godfrey et al., 2007). Common PPCPs reported include ibuprofen, paracetamol, salicylic acid, and triclosan. Life-style compounds include nicotine, and its metabolite cotinine. EDS include E2, oestrone bisphenol A and NP (Swartz et al., 2006). These EOCs were detected in concentrations between $10-10^{3} \mathrm{ng} / \mathrm{L}$. While at close proximity to the sources concentrations may be high, the generally low volumes of leachate from this type of source means that total EOC loading to groundwater are low on a regional scale, and there is a high potential for dilution and attenuation.

The use of veterinary antibiotics in concentrated animal feeding operations (CAFOs) is a growing concern as an important source of environmental contamination. This is of particular relevance in the USA, parts of Europe and Asia where intensive rearing of livestock is becoming more common (Thorne, 2007, Bradford et al., 2008, Chomycia et al., 2008, BartletHunt et al., 2010). A significant proportion of the antibiotic given (and degradates) passes through the livestock and is excreted and stored in waste lagoons and so poses a potential threat to groundwater sources through leakage from the lagoons or when the waste is spread on the land. In dairy waste lagoons, the endogenous oestrogens E2 and oestrone and the androgens testosterone and androstenedione have been detected at concentrations as high as 650 ng/L (Kolodziej et al., 2004).

\subsubsection{Diffuse sources}

Application of manure, and bio-solids from sewage sludge processing, to the land surface is an important part of waste management strategy, and has the added benefit of enhancing soil nutrient levels (e.g. EC, 2011). However, the incomplete removal of EOCs during waste water treatment may result in residual concentrations in bio-solids that are applied to soil (Clarke 
and Smith, 2011). Due to their relatively high concentrations in waste water related bio-solids and their relatively high solubility two types of halogenated hydrocarbons (perflurochemicals and polychlorinated alkanes) are considered important potential groundwater contaminants from applications to soil and surface runoff (Clarke and Smith., 2011). Sarmah et al. (2006) reviewed the occurrence and fate of veterinary antibiotics in the environment and reported the occurrence of a range of veterinary antimicrobials at low concentrations in groundwater which were attributed to agricultural practices including the application of manure. Buerge et al. (2011) reported the occurrence of saccharin in groundwater at a pumping station in Switzerland, with concentrations up to $260 \mathrm{ng} / \mathrm{L}$, after application of pig manure despite the fact that biological mineralisation in soil was rapid (90\% after two months incubation).

A range of antimicrobial compounds attributed to soil manure applications have been reported in groundwater sources in China (Hu et al., 2010). Groundwater concentrations were reported between 5-42 ng/L, and residues were found to be higher during wetter periods compared to dry summer months. The concentrations detected in groundwater were explained in terms of solubility and $\mathrm{K}_{\mathrm{ow}}$. In the UK there is guidance provided by the Environment Agency (EA, 2011) regarding the application of chicken manure contaminated with veterinary medicines, used to treat broilers, owing to the potential contamination of surface and groundwater bodies. While it is has been shown that manure and biosolid derived EOCs can reach groundwater resources, they are more likely to do so in significant concentrations via indirect routes such as surface water- groundwater (GW-SW, see following section) exchange from runoff rather than downward migration due to attenuation mechanisms in the soil and unsaturated zone. The practice of applying bio-solids to soil is a critical part of the current waste management practice globally, and will continue to be so in the future. Therefore, these sources are likely to continue to be important potential sources of EOC contamination in groundwater. 
Surface waters contain higher concentrations, and a larger range of EOCs than groundwaters (e.g. Focazio et al., 2008), and are therefore an important source and pathway of EOC pollution of groundwater bodies as a result of both natural (Lapworth et al., 2009) and engineered GW-SW exchange processes (Drewes, 2009). The more frequent occurrence of EOCs in surface waters reflects the direct input from waste water sources, short residence times and the limited dilution and attenuation capacity of surface water compared to groundwater (Barnes et al., 2008). Once EOCs enter a surface water course they may stay in the surface water body or by lateral or vertical hydraulic exchange, through the hyporheic zone, can be transferred to a groundwater body (Lewandowski et al., 2011). Where the regional groundwater table is below the surface water level, for example in more arid regions, the surface water may recharge directly into the unsaturated zone beneath the river course. Through such mechanisms surface waters can be considered a source and pathway of groundwater pollution. Recently, EOCs have been used to great effect to trace SW-GW exchange processes and as markers of waste water sources (e.g. Buerge et al., 2009; Mueller et al., 2011), this is covered in more detail in section 6 . This process is particularly important in aquifers below and adjacent to water courses, for example in shallow alluvial aquifers, which are very important source of drinking water in many parts of the world.

Managed aquifer recharge (MAR) refers to the use of surface water sources (including treated waste water) to artificially recharge an aquifer. It is a particularly useful management tool in semi-arid regions where water resources are scarce (Gale and Dillon, 2005; Drewes, 2009; Lev et al., 2011). It is used to replenish aquifers, use them as natural temporary storage systems, and in some cases manage river flow (Bouwer, 2002; Daher et al., 2011). However, artificial recharge can in some instances short-circuit natural attenuation mechanisms in the soil and subsurface leading to potential long term contamination of groundwater resources. 
Diffuse leakage from reticulated sewerage systems may pose a significant risk for EOC pollution in groundwater as it by-passes natural attenuation mechanisms in the subsurface (Ellis, 2006). This is a particular risk in urban land use settings, especially where the systems are in poor repair (Foster et al., 1998; Morris et al., 2005; Morris and Cunningham, 2008; Rueedi et al., 2009). Aerial sources from industry, transport and agriculture provide a diffuse and low loading to the land surface (Leister and Baker 1994; Villanneau et al., 2011). Due to the low concentrations and high attenuation potential in the subsurface, particularly in the soil zone, these types of diffuse sources are not considered significant for groundwater pollution.

\subsection{The fate of EOCs in the subsurface}

Recent studies investigating the fate of EOCs from treated wastewater effluents at artificial recharge sites and tracer tests following EOC injection in the subsurface have showed that while natural attenuation is high for many compounds it is certainly not complete, with some compounds behaving in a conservative way during recharge (e.g. Cordy et al., 2004; Barber et al., 2009; Fernandez et al., 2011; Cabeza et al., 2011; Laws et al., 2011).

The fate of any given contaminant in the subsurface environment will depend upon both its physicochemical properties, such as its solubility in water, $\mathrm{K}_{\mathrm{ow}}$ and $\mathrm{D}_{\mathrm{ow}}$ (Sedlak and Pinkston, 2001; Wells, 2006) and other environmental characteristics. Indeed, the contaminant properties as well as groundwater residence time, redox conditions and total loading will be important in determining presence and persistence in the subsurface and groundwater. EOCs applied to the soil surface will potentially migrate through the soil zone (Scheytt et al., 2004), the unsaturated zone and into the saturated zone (Oppel et al., 2004., Snyder et al., 2004; Zuehlke et al., 2004). The main processes controlling EOCs during subsurface migration are sorption mainly to organic matter and clay minerals, ion exchange in the soil and aquifer, and microbial degradation or transformations. 
The following sections review the processes that potentially control EOC attenuation and migration in and to the subsurface including hydraulic/physical characteristics, sorption processes and biodegradation/redox controls.

\subsubsection{Physical/hydraulic controls}

Groundwater contamination by organic compounds is affected by physical/geological controls (i.e. intrinsic vulnerability), such as the degree of confinement/concealment of an aquifer, the hydraulic properties of the aquifer and overlying soil (e.g. Worrall and Kolpin, 2004).

Groundwater age tracers (e.g.CFCs and tritium) are now starting to be used to understand organic contaminant occurrence in groundwater from agricultural and amenity uses (e.g. Lapworth and Gooddy, 2006; Gourcy et al., 2009) and urban waste water sources (Fram and Belitz, 2011).

A recent study in France (Faille, 2010) found that carbamazepine was detected at around 20\% of sites (up to $16 \mathrm{ng} / \mathrm{L}$ ) in confined and semi-confined groundwaters. This was found to be less than in unconfined areas where $45 \%$ of sites had detections and measured concentrations up to $167 \mathrm{ng} / \mathrm{L}$. In a study in the USA targeting wells with suspected sources Barnes et al. (2008) found that shallower wells had significantly higher detections of indicator wastewater compounds including pharmaceuticals. A recent study carried out in California, USA, by Fram and Belitz (2011) found low detection frequencies (2.3\%) for pharmaceuticals in groundwaters used for public drinking water supply. This was in part due to the deep nature of the supply boreholes and low proportion of modern groundwater found in these sources, however, occurrence of pharmaceuticals was not found to be correlated to well depth.

Groundwater resources in karstic zones are particularly at risk from contamination from diffuse and point sources of EOCs due to the rapid flow mechanisms limiting natural attenuation in the unsaturated and saturated zone during recharge (Katz et al., 2009; Hillebrand et al., 2011). The relatively short residence times (high transmissivity) and 
exchange pathways with surface water bodies mean that shallow alluvial aquifers are also highly susceptible to EOC contamination (Bruchet et al., 2005; Rabiet et al., 2006; Osenbruck et al., 2007; Nakada et al., 2008).

\subsubsection{Surface sorption and EOC molecular properties}

Sorption onto matrix surfaces (soil and unsaturated zone) during groundwater recharge and onto materials of the saturated zone is an important process able to attenuate EOCs in the subsurface and is a key factor in terms of EOC accumulation, bioavailability and degradation. Studies investigating sorption of EOC onto soils reveal the major role of soil carbon organic and clay (e.g. Casey et al., 2004; Wang et al., 2009; Olshansky et al., 2011) for many molecules while sorption on geological materials deeper in the unsaturated zone and saturated zone has been less well studied. Ionic molecules can have more complex behaviour as their fate varies with $\mathrm{pH}$ conditions. Attenuation of the cationic $\beta$-blocker was investigated by Schaffer et al. (2011) under realistic competitive cationic conditions (Ca 4-400 mg/L). The transport of atenolol was reduced with decreasing cationic concentration due to reduced competition for negatively charged sites. In contrast diclofenac and ibuprofen are negatively charged under environmental conditions and thus are only weakly adsorbing to neutral surfaces or and are not adsorbed to negatively charged subsurface matrices in chalk aquifers. Comparatively low partitioning coefficients $(\mathrm{Kd})<2$ have been reported for adsorption to aquifer sediments (Scheytt et al., 2005). These findings may have important implications for ionic EOC fate during changes in major ion chemistry (e.g. natural episodic recharge, salt water intrusion or artificial waste water recharge). Some studies reveal interactions with metals have important implications for the transfer of EOCs in soil, for example tetracycline antibiotics (Sassman and Lee, 2005).

Two studies by Scheyett et al. $(2004,2005)$ showed that the mobility and attenuation of diclofenac, ibuprofen, and propyphenazone is in the same range for experiments under 
saturated and unsaturated conditions whereas carbamazepine had a significantly lower sorption and elimination under unsaturated conditions. There is clear evidence that some compounds, e.g carbamazepine, are resistant to various natural attenuation and treatment processes following observations in both field scale experiments and at the catchment scale (Glassmeyer et al., 2005; Clara et al., 2004, Scheytt and Müller, 2011). This is due in part to its resistance to hydrolysis and neutral charge at pHs' found in most groundwater environments which results in poor interaction with mineral surfaces with a largely negative charge. Shinohara et al. (2006) demonstrated that amide EOCs (e.g., crotamiton, carbamazepine, or diethyltoluamide) were poorly attenuated in the soil zone $(<30 \%)$ compared to phenolic and carboxylic compounds (ibuprofen, 92\%; triclosan, 99\%). These findings are broadly consistent with the more widespread detection of the amide EOCs (e.g. crotamiton) in urban groundwater and no or less-frequent detection of the phenolic and carboxylic EOCs (e.g. Nakada et al., 2008; Stuart et al., 2011). These studies demonstrate why amide EOCs (i.e., crotamiton and carbamazepine) are perhaps more conservative tracers of sewage inputs to groundwater, compared to phenolic or carboxylic EOCs.

While molecular properties (see Hansch et al., 1995) have been successfully used to discriminate between polluting and non-polluting pesticide compounds in groundwater (e.g. Worrall. 2001), for many emerging contaminants key properties that can govern their fate in the subsurface remain unknown and this is a priority area for future research.

\subsubsection{Biodegradation and redox controls}

The role of microorganisms in the degradation of EOC has been clearly demonstrated, especially in the soil zone (e.g. Alvarez and Illman, 2006; Semple et al., 2007; Wick et al., 2007). However, in groundwater, i.e. in the unsaturated and saturated zone, microorganisms are less numerous and probably less diverse and there are also variable redox conditions 
which may limit biological activity (Johnson et al., 1998). The degradation pathways of EOC are often significantly faster under aerobic conditions compared to anaerobic conditions (Watanabe et al., 2010; Godfrey et al., 2007; Barnes et al., 2004). As such, redox controls are a common theme in EOC persistence in groundwater from a range of sources including landfills, septic tanks and CAFO lagoons.

The redox conditions and mixtures of EOCs in certain groundwater systems and contaminant plumes may preserve EOCs for longer than would be expected under aerobic conditions and as a result they can behave in a more conservative manor (Carrara et al., 2007; Hohenblum et al., 2004). A recent degradation study by Burke et al (2011) using microcosm experiments of the analgesic compounds phenazone and propyhenazone and their degradates reported the degradation of six of the seven investigated compounds was strongly influenced by the prevailing redox environment. In this study, most parent compounds and degradates showed better removal under oxic conditions, whereas they persisted in the anoxic conditions.

While caffeine and paracetamol (also called acetaminophen) are used in much higher concentrations both are more biodegradable during waste water treatment and transport in the subsurface (e.g. Benotti and Brownawell, 2009) and as such are generally detected less frequently compared to other EOCs such as carbamazepine and sulfaethoxasole which are more resistant to biodegradation. An important factor associated with EOC persistence in the subsurface from landfill plumes is the development of a redox zone within the contaminant plume (e.g. Christensen et al., 1992). This reducing environment has been shown to be important in controlling the transport and fate of some organic compounds with otherwise high attenuation potential (Williams et al., 1984; Holm et al., 1995). For sources of contamination from septic tanks it has also been suggested that a redox-mediated persistence of EOCs is important controlling factor (Carrara et al., 2007). 
Veterinary antibiotics have been investigated by Watanabe et al. $(2008,2009)$ and BartletHunt et al. (2010) in various environmental compartments including groundwater below animal waste lagoons, as well as shallow groundwater from areas where animal waste had been applied to fields. Veterinary antibiotics (Lincomycin, monensin and erythromycin) have been found to persist ( $>100 \mathrm{ng} / \mathrm{L}$ ) in groundwaters below poorly sealed lagoons compared to the surface and soil samples. The anaerobic groundwater conditions are thought to contribute to the persistence of these antibiotics in the groundwater after they have been leached from the base of the lagoon. Antibiotic (sulfamethazine) concentrations $(0.6 \mathrm{ng} / \mathrm{L})$ in groundwaters where manure has been applied to soils were found to be two orders of magnitude lower than below animal waste lagoons (Watanabe et al., 2010). These observations were consistent with greater dilution and attenuation potential and lower total loading in soil-applied manure compared to the waste lagoon. In addition, it was observed that the contrasting redox conditions below the lagoons (anaerobic) and the manure-applied sites (aerobic) may also strongly influence the potential degradation pathways (Watanabe et al., 2010). The aerobic conditions in soils contrast with those below farm waste lagoons where veterinary antibiotics were detected and suggest a redox control on its fate in groundwater.

\section{Occurrence and concentrations of EOCs in groundwater}

A large number of studies published since 1993 that report groundwater EOC results have been included as part of this study and data compiled for the maximum concentrations observed for the potential sources cited (See Table S1 for details). The maximum concentration for each compound was chosen for comparison as this was found to be the most commonly cited value in published studies; due to the very large proportion of non-detects (often $>90 \%$ ), and the low sample numbers, calculating the mean value for many compounds is meaningless (Helsel, 2005). While it is clear from reviewing the literature that the vast 
majority of groundwater resources do not contain EOCs in concentrations that would be considered toxic and/or harmful, due to natural attenuation and dilution mechanisms, there is a large variety of EOCs found in groundwater proximal to important direct and indirect sources (e.g. artificial recharge and surface water), and in some cases the concentrations are significant (>100 ng/L). The combined toxicity of multiple contaminants is not well understood at present (Brooks et al., 2009). In addition, there are a number of key EOCs that have a global footprint, and are frequently detected in groundwater resources.

Figure 3 is a box-plot of maximum EOC concentration in groundwater grouped as follows: steroids and hormones, sweeteners and preservatives, 'life-style' compounds, industrials, PPCPs and veterinary medicines (note the log scale on the y-axis). Suspected outliers $(+)$ are $25^{\text {th }}$ and $75^{\text {th }}$ percentile $+/-1.5(\mathrm{IQR}), \mathrm{n}=$ number of results, $\mathrm{c}=$ number of different compounds for each group. Table 1 summarises the lowest, average and highest maximum concentrations found in groundwaters for individual EOCs that were reported in at least four separate studies, for a full list of results for all 180 compounds see Table S1 in supplementary information. Maximum concentrations for the most commonly detected compounds in groundwater were reported over the range $40-10^{4} \mathrm{ng} / \mathrm{L}$. The six most commonly reported compounds globally were as follows: carbamazepine ( 23 studies, average max. conc. $=5 \mathrm{x}$ $\left.10^{3} \mathrm{ng} / \mathrm{L}\right)$, sulfamethoxazole $(15,252 \mathrm{ng} / \mathrm{L})$, ibuprofen $\left(14,1.5 \times 10^{3} \mathrm{ng} / \mathrm{L}\right)$, caffeine $(14,9.8 \mathrm{x}$ $\left.10^{3} \mathrm{ng} / \mathrm{L}\right)$, diclofenac $(11,121 \mathrm{ng} / \mathrm{L})$ and Bisphenol A $\left(9,2.5 \times 10^{3} \mathrm{ng} / \mathrm{L}\right)$. For a full breakdown of the occurrence of all the EOCs in this study please refer to Table S1 in the supplementary material.

For these more frequently reported compounds (Table 1) there is no clear relationship between occurrence (average or highest maximum concentration) and $\mathrm{K}_{\mathrm{ow}}$ or frequency. This is not surprising as the overall loading on the environment, transport time through the unsaturated zone, toxicity to microbes and other physical properties such as charge, size and 
functionality are all important factors in controlling the fate of EOCs in environment and their subsequent occurrence in groundwater. Physical properties of EOCs and the maturity of treatment systems are also important factors that control the attenuation of EOCs during water treatment and their subsequent emission into the aquatic environment.

\subsection{Pharmaceuticals}

The most frequently reported group of compounds were pharmaceuticals $(n=16)$, see Table 1 . These included 5 analgesics, 4 anti-inflammatory drugs, three antibiotics, one anti-epileptic (carbamazepine), one barbiturate (primidone), a commonly used insecticide (DEET), an x-ray contrast agent (iopamidol) and clofibric acid, reported in these studies as a metabolite of the lipid regulator clofibrate (clofibric acid is also a pesticide). Analgesics were reported to occur in groundwater in the following order of maximum concentration; paracetamol, $(n=8)>$ ibuprofen $(n=14)>$ phenazone $(n=4)>$ propyphenazone $(n=5)>$ salicylic acid $(n=4)$, and antiinflammatory drugs in the following order of maximum concentration ibuprofen $(n=14)>$ ketoprofen $(n=6)>$ diclofenac $(n=11)$. The major source of analgesics and antiinflammatories was from waste water, including bank infiltration, artificial recharge, leakage from urban sewage systems, septic tanks (e.g. Heberer et al., 1997; Heberer, 2002, Reddersen et al., 2002; Hinkle et al., 2005; Verstraeten et al., 2005; Ellis, 2006; Carrara et al., 2007).

The three most commonly reported antibiotics were found to occur in the following order of maximum concentration, triclosan $(n=6)>$ sulfamethoxazole $(n=15)>$ lincomycin $(n=5)$, in addition erythromycin was reported in three different case studies. The maximum concentrations for antibiotics were reported in the range $5.7-2 \times 10^{3} \mathrm{ng} / \mathrm{L}$, with the major sources being waste water sources, landfills, septic tanks and animal waste lagoons (e.g. 
Barnes et al., 2004; Carrara et al., 2007; Watanabe et al., 2010). In one study in Denmark Holm et al. (1995) reported sulfonamides in groundwater samples down gradient of a landfill site at concentrations in the range $10^{4}-10^{6} \mathrm{ng} / \mathrm{L}$, however, generally antibiotics are detected in low concentrations compared to other more commonly occurring groundwater EOCs.

Less widely reported pharmaceuticals include a range of compounds associated with skin care products including UV blockers (oxybenzone and drometrizole), isopropyl myristate, phenoxy-ethanol and lilial (Snyder et al., 2004; Stuart et al., 2011). Preservatives detected in groundwater include a series of paraben compounds (fungicide/microbiocide) which are used in food, creams and other personal care products. Methylparaben was detected relatively frequently (c. 2\%) in UK groundwaters (Stuart et al., 2011) with a maximum concentration of $5 \times 10^{3} \mathrm{ng} / \mathrm{L}$ and may be potentially a useful marker of waste water pollution in the freshwater environment.

\subsection{Veterinary medicines}

An important sub-group of pharmaceuticals are compounds used exclusively for veterinary purposes. The antibiotic sulfamethazine has been reported in groundwater several studies $(\mathrm{n}=5)$, with maximum concentrations ranging from 120-616 ng/L, and the highest concentrations being associated with leaching from farm waste lagoons, although it has also been reported in groundwater reconnaissance studies in Germany, USA and Switzerland (Hirsch et al., 1999; Barnes et al., 2008; NAQUA, 2009). Two other veterinary antibiotics reported in groundwater include monensin and tylosin (Watanabe et al., 2008; Bartel-Hunt et al., 2011). Waste lagoons are also potential sources of hormones and steroids, however, these appear to be largely attenuated in groundwater conditions (Kolodziej et al., 2004). While the practice of meat production on CAFOs is perhaps more prevalent in the USA compared to 
Europe, there has been a significant concentration of animal production in Europe over recent decades (Thorne, 2007), and this continues to pose a potential threat to groundwater resources.

\subsection{Industrial compounds}

Two phenolic compounds (bisphenol A and the metabolite NP, both known endocrine disruptors), a fire retardant (tri(2-chloroethyl) phosphate) and the musk galaxolide were among the most frequently reported compounds (Table 1). Other detergents, plasticisers and fire retardants have been reported (Table S1). Bisphenol A is used as a plasticiser and common sources include treated waste water as well as septic tanks and landfills (Osenbruck et al., 2007; Buszka et al., 2009; Musolff et al., 2009). Other groups of detected industrial compounds include solvent stabilisers, surfactants and corrosion inhibitors (Barnes et al., 2008, Loos et al., 2010, Stuart et al., 2011). Tonalide, also a musk, was reported in three different studies across Europe (Musolff et al., 2009; Bruchet et al., 2005 and Stuart et al., 2011). Fluorinated organic compounds have a large range of uses including as refrigerants, fire retardants, in packaging and as protective coatings and there is growing interest in there environmental fate and occurrence (de Voogt et al., 2006). A study in the UK detected perfluorinated compounds in $26 \%$ of groundwater monitoring sites $(n=219)$ at concentrations $>0.3 \mu \mathrm{g} / \mathrm{L}$ (EA, 2007), groundwater contamination from chloroflurocarbons is widely reported (e.g. Shapiro et al., 2004; Morris et al., 2005).

\subsection{Life-style compounds}


Two life-style compounds were found in more than four case studies, caffeine $(n=14)$ and the nicotine metabolite cotinine $(n=4)$. Maximum caffeine concentrations were reported between $13-11 \times 10^{4} \mathrm{ng} / \mathrm{L}$, confirming its use as a marker of anthropogenic activity and waste water contamination (Loos et al, 2010). Common sources of caffeine include septic tanks as well as waste water treatment discharge to surface water and groundwater-surface water exchange in alluvial groundwater systems (e.g. Swartz et al., 2006; Godfrey et al., 2007; Rabiet et al., 2006). Nicotine was only reported in two case studies (Stuart et al., 2011; Godfrey et al., 2007).

\subsection{Endocrine disrupting substances}

The most commonly reported known estrogenic hormones were E2 $(n=4)$ and its metabolite oestrone $(n=6)$. These were reported in low concentrations $(0.1-120 \mathrm{ng} / \mathrm{L})$ compared to

pharmaceuticals (Figure 3). While four of the more frequently reported compounds are known EDS (estrone, E2, NP and bisphenol A), there are at least a further 8 compounds that are potential EDS, including fragrances; galaxolide and tonalide, and other non-steroidal pharmaceuticals; clofibric acid, paracetamol, ibuprofen, naproxen, diclofenac and fluoxetine (Caliman and Gavrilescu, 2009). The endocrine disrupting activities of oestrone and E2 are comparable, and much greater than that of NP and bisphenol A (see Hohenblum et al., 2004 and references therein).

\subsection{Food additives}


Food additives detected in groundwater include the sweetners acesulfame, saccharin and sucralose (Buerge et al., 2009; Scheurer et al., 2008) as well as other preservatives such as parabens. This group of compounds have not been widely studied in groundwater, but show potential as a marker compounds to trace waste water sources and as such are likely to be included in future studies.

\section{Regional, national and pan-national reconnaissance surveys}

A summary of EOC occurrence and frequency for selected larger-scale studies is shown in Table 2. These confirm that EOCs are widespread in both groundwater and surface water as found in other studies, e.g.Tracol and Duchemin (2009). The following EOCs have been detected in drinking water sources, usually with concentrations at the ng/L level: Carbamazepine (anti-epileptic) and sulphamethoxazole (antibiotic) have been detected in a number of studies (e.g. Stolker et al. 2004, Stackelberg et al. 2007), the veterinary antibiotic compound tylosin (Zuccato et al. 2000); steroids by comparison have rarely been observed in treated drinking water (Fawell et al., 2001; Rodriguez-Mozaz et al., 2004; Chen et al., 2007), with the exception of estrone (metabolite); $17 \alpha$ - and 17 $\beta$-oestradiol and the contraceptive ethinyloestradiol (Kuch and Ballschmiter, 2001); natural hormones (oestriol and progesterone) were found in drinking water from Spain (Kuster et al., 2010).

Compared to surface water samples the groundwaters across Europe were found to be less contaminated, with a $25 \%$ frequency of detection for all compounds (Loos et al. 2010). The results compared well with the findings of Barnes et al. (2008) and Focazio et al. (2008) for the USA in terms of frequency for selected compounds. In a reconnaissance survey for streams Kolpin et al. (2002) found the detection frequency for the same analytical suite as 
used by Barnes et al. (2008) for groundwater to be greater by a factor of 2.4. However, it is noteworthy that triclosan was not detected frequently in the Europe wide study in contrast with studies in the USA.

Table 3 shows the frequency and summary statistics for a selection of PPCPs (sulfamethoxazole, ibuprofen, carbamazepine), industrials (NP and bisphenol A) and caffeine that have been detected in regional and national scale groundwater reconnaissance studies. It should be noted that site selection criteria and sample numbers are not consistent across the studies. Barnes et al. (2008) used criteria to select sites with potential contamination, while in the case of Loos et al. (2010) and Fram and Belitz (2011) sites were selected without strict criteria. This explains the significantly lower detection frequency for compounds found in the study by Fram and Belitz (2011), compared to Barnes et al. (2008). In the case of the study in UK (Stuart et al., 2010) no criteria based on potential EOC occurrence was used in site selection and this has twice as many samples compared to any other study. It can be seen that there is considerable variation in the frequency of detects for all six commonly detected compounds between studies carried out in different countries and within the same country. The range of detection frequency for sulfamethoxazole was between $0.41-24 \%$, ibuprofen 0 $6.7 \%$, carbamazepine $1.2-42 \%$, NP 1.1-69\%, bisphenol A $8-59 \%$ and caffeine $0.24-83 \%$. The recent studies by Loos et al. (2010) and Barnes et al. (2008) stand out as having high frequencies for a number of these commonly detected EOCs compared to other studies (see Tables 2 and 3 ).

The five most commonly reported PPCPs in this study (see Table 1 and 2) have all been licensed for use in the USA for more than two decades, and in the case of carbamazepine, sulfamethoxazole, ibuprofen and clofibrate, more than three decades (FDA, 2011). Besides their intrinsic properties, their frequent reporting (Table 1) is likely due to their long history of use in Europe and North America. Their widespread occurrence in regional groundwater 
reconnaissance studies (see Table 2 and 3) could also be due to the fact that they have had sufficient time to travel through the unsaturated zone, as well as their prolonged release to the environment, particularly during the 1970 s and 1980s when water treatment processes were less advanced and less able to attenuate these contaminants. As a result more recently introduced pharmaceuticals (e.g rufinamide, also an antiepileptic drug, with a $\mathrm{K}_{\mathrm{ow}}$ similar to cabarmazepine) may not be observed in groundwater bodies for some years.

Figure 4 shows a cumulative probability distribution of maximum EOCs (180 compounds, see Table S1) concentrations in groundwater for both targeted and non-targeted studies. This data was compiled from 74 published studies from 14 countries. Data from both study types show a comparable range of maximum EOC concentrations. Maximum concentrations have a lognormal distribution and the number of compounds detected are comparable. Overall, reconnaissance studies have higher median concentrations $(325 \mathrm{ng} / \mathrm{L}$, note log scale in Figure 3) compared to targeted studies $(155 \mathrm{ng} / \mathrm{L})$. A Wilcoxon rank sum test shows that the median values are significantly different $(p>0.01)$. This is probably because the reconnaissance studies are from investigations with much larger sample sizes (typically $>50$ ) and larger analytical suites (typically $>50$ compounds) compared to targeted studies (see Table 2 for details).

\section{EOCs as groundwater tracers and modelling transfer to groundwater}

Fluorinated compounds have been used for many years as important quantitative tracers for groundwater dating (e.g. Busenberg and Plummer. 1992; Darling et al., in press). Recent reviews e.g. (Benotti, 2006; Dickenson et al., 2011) have assessed the use of a range of EOCs as tracers in the aquatic environment. EOC tracers that have been used in surface and 
groundwater systems include Gd (NMR source) caffeine, gemfibrozil, carbamazepine and nicotine derivatives (Seiler et al., 1999; Buerge et al., 2003, 2008; Clara et al., 2004). Applications include quantitative and qualitative experiments using single tracers as well as EOC ratios. Caffeine was used as a tracer in the karstic groundwater of southwest Germany (Hillebrand et al., 2011) to understand the impact of waste water pollution. Carbamazepine has also been used to evaluate and quantify groundwater contamination from waste water sources (Gasser et al., 2010; Lev et al., 2011). The chiral nature of EOC including pharmaceuticals and musks, have potential important applications for characterising the sources, fate and pathways of contaminants in groundwater (Kholer et al., 1997; Buser et al., 1999; Wong. 2006).

To date most modelling studies have been focused on evaluating potential environmental concentrations in various fresh water environments (Kümmerer et al., 2005; Kümmerer, 2008). A recent paper by Domènech et al. (2011) showed the application of a model to assess the fate of a range of commonly used EOCs (Spain) and modelled potential surface water concentrations were found to be broadly comparable with measured observations. The fate of pharmaceuticals has been modelled in groundwater as a result of bank infiltration (Zippel et al., 2010); this is a commonly used treatment technique in several river basins including the Rhine, Danube and Meuse and continues to be an important source of EOC in groundwater. Modelling studies in the soil zone have shown that sulfonamide antibiotics are readily desorbed from soils and are a potential threat to groundwater and surface water resources (Unold et al., 2009; Srivastava et al., 2009).

\section{Impacts on groundwater resources}

Over the last decade the development of broader, more rapid and cost effective screening tools for EOCs has enabled environmental concentrations of EOCs in groundwaters to be 
better assessed. Groundwater resources have been shown to be polluted with a large range of EOCs that are detected at environmentally significant concentrations as a result of recent anthropogenic activities as well as historical environmental pollution. This review highlights the widespread contamination of groundwaters by a range of PPCPs, industrial compounds and life-style compounds, with carbamazepine, sulfamethoxazole, ibuprofen, bisphenol A and caffeine being the most widely reported compounds. Environmentally significant concentrations (100-10 $\mathrm{ng} / \mathrm{L})$ of a range of EOCs, including a number of EDS, are being detected in groundwaters globally.

However, compared to surface waters the occurrence and fate of EOCs in groundwater has received little attention. To date research has focused on site-specific EOC pollution in groundwater, largely from waste water sources. While these studies have been critical in developing our understanding of groundwater contamination by EOC they have primarily focused on point source pollution. Many national and regional studies have been biased towards sites with 'potential' contamination so the real frequency of occurrence and distribution in the environment remains poorly understood. More regional-scale studies are needed to fully assess the occurrence of EOC in groundwater, and characterise the spatial and temporal nature of EOC contamination, in agricultural biosolids and manure, sources from diffuse urban leakage as well as transport networks (Musolff et al., 2009; Stuart et al., 2011). While EOC occurrence in some parts of Europe (generally the more industrialised regions) and North America has been better characterised than most, there is a clear paucity of available information on EOC occurrence in groundwaters across large parts of Europe, Asia and Africa and South America. Groundwaters from these areas are at risk from contamination, a problem compounded by limited regulation for emissions to the environment (e.g. Stuart et al., 2001; Alemaw et al., 2004; Covaci et al., 2006; Hoai et al., 2010; Chen et al., 2011). Recent studies show that despite improvements in water treatment processes and their ability 
to attenuate EOCs, observations in surface and groundwaters impacted by waste water treatment, and finished drinking water, suggest that significant concentrations are still being released to the aquatic environment and can bypass the various treatment processes (e.g. Benotti et al., 2009; Houtman, 2010; Dickenson et al., 2011). In many parts of the world water treatment options to remove EOCs are limited or not available.

More arid environments have been shown to be particularly susceptible to groundwater contamination by EOCs due to intentional and unintentional recharge of waste water sources (Drewes et al., 2003; Drewes, 2009; Gasser et al., 2010; Cabeza et al., 2011). The ratio between natural recharge and artificial recharge is such that there is less potential for dilution and natural attenuation. As a result the impact on groundwater quality from these activities is greater and perhaps less sustainable over long time periods. This is a very real challenge as artificial recharge remains an important water resource management option in arid, water scarce areas of the world (Drewes, 2009; Fram and Belitz, 2011).

Groundwaters that are already contaminated with EOCs may pose a hazard for decades to come owing to relatively long residence times and persistence due to reducing chemistry and relatively low microbial degradation rates. They may be an important source of EOC in surface waters through baseflow inputs and GW-SW exchange. Alluvial and karstic aquifers are particularly susceptible to contamination, and have been the focus of many of the groundwater studies to date (e.g. Drewes et al., 2003; Katz et al., 2009; Einsiedl et al., 2010). Almost half of the studies $(n=11)$ where carbamazepine has been reported have been in shallow alluvial groundwater systems, and karstic systems $(n=2)$, while a number of studies do not specify a particular geology. 


\section{Areas for further research}

The use of EOCs in groundwater as novel tracers for waste water sources is a developing research area. This may have most value in elucidating proximal sources of groundwater pollution due to the large attenuation/dilution potential of groundwater systems. However, whether multiple contaminant sources of EOCs in groundwater can be discriminated remains unclear and warrants further investigation. Many of the frequently observed EOCs in groundwater (e.g. carbamazepine and caffeine) are associated with multiple sources. To date few studies have coupled EOCs with other established environmental tracers (e.g. isotopes, groundwater residence time tracers) to develop process understanding of their fate and transport in the subsurface environment. The transport of groundwater and contaminants through the unsaturated zone may take considerable time and therefore result in a time lag before they impact groundwater quality. Both field and modelling studies are needed to develop our understanding of the fate of EOC in the unsaturated zone.

Fundamental research on the sorption and degradation of EOCs in soil and aquifer material is required to develop predictive modelling capabilities for EOC in the subsurface environment. Research is needed to assess the importance of different sources and transport processes in addition to the chemical properties of the EOCs themselves in controlling their occurrence in groundwater. Investigating the fate and degradation pathways of EOCs may be greatly facilitated using isotope labelling approaches in field and laboratory studies (e.g. Nowak et al., 2011).

Molecular topology and quantitative structure-activity relationship (QSAR) type modelling is being increasingly used as a tool to screen potentially mobile EOCs in treatment processes and for environmental toxicological studies (e.g. Jaworska et al., 2002; Cronin et al., 2003). Given the large number of potential compounds and lack of fundamental properties for many 
EOCs this approach has obvious future applications for understanding the fate of EOCs in the environment including the risk of groundwater pollution (Worrall, 2001).

There has been little attempt to date to understand the importance of large scale hydrogeological processes (e.g. residence time or aquifer confinement) or redox controls on the occurrence and fate of many groups of EOCs in groundwater including PPCPs, industrial chemicals and life-style compounds compared to pesticides (e.g. Worrall and Kolpin, 2004, Worrall and Besien, 2005).

Continuing research on partitioning of EOC between the dissolved and colloidal phase is needed. Colloidal transport may be an important pathway for EOC within the subsurface, allowing EOCs to be transported further and faster than in the dissolved phase. The interaction between EOCs and model colloids such as Fe-oxyhydroxides and fulvic-like substances, and naturally heterogeneous colloids warrants further investigation. The fate of EOCs in the hyporheic zone (the zone of interaction between surface water and groundwater) is as yet poorly understood and is likely to be an important area for future research (e.g. Lewandowski et al., 2011, Banzhaf et al., 2011).

This review has highlighted the fact that degradates of EOCs are often found more frequently and in greater concentrations compared to parent compounds (e.g. cotinine, estrone, clofibric acid, and NP). This has also been found to be the case for many pesticides (e.g. Kolpin et al., 2000, Lapworth et al., 2006) and reinforces the need to monitor and regulate for degradates of EOCs as well as their parent compounds. A related area requiring continued research is the effect of antibiotics on microbes and the development of antibiotic-resistant bacteria in the subsurface, for example under waste lagoons (Pruden et al., 2006, Mckinney et al., 2010) and their effects on soil microbial communities (Gutierrez et al., 2010).

While subsurface transport may attenuate a large proportion of EOCs, in some instances groundwaters may continue to be a source of EOC for tens of years as a result of long 
residence times and low microbial populations in groundwater systems. In the next decades, more of these EOCs are likely to have drinking water standards, environmental quality standards and/or groundwater threshold values defined, and so a better understanding of the spatial and temporal variation is a priority. This may be facilitated by the deployment of novel sampling techniques for detecting very low concentrations of EOCs in groundwaters (StuerLauridsen, 2005).

\section{Conclusions}

1. This review highlights the widespread contamination of groundwater resources by a large variety of emerging contaminants that are detected at potentially environmentally significant concentrations as a result of both recent and historical activities. Important EOCs include a range of PPCPs, industrial and life-style compounds, with carbamazepine, sulfamethoxazole, ibuprofen, bisphenol A and caffeine being the most widely reported compounds. Environmentally significant concentrations $\left(10^{2}-10^{4} \mathrm{ng} / \mathrm{L}\right)$ of a range of EOCs, including a number of EDS, are being detected in groundwaters globally. Many of these EOCs are among the highest priority substances for treatment and regulation both in terms of their potential environmental and human health effects.

2. Compared to other freshwater resources the occurrence of EOCs in groundwater is poorly characterised. Many national and regional studies have been biased towards potentially contaminated sites so the actual frequency and distribution in groundwater remains largely unknown. So far site-specific research has been directed towards waste water point sources, there is currently limited understanding of the risk of groundwater pollution from more diffuse sources such as biosolids and urban sewage leakage. More systematic regional-scale studies are needed to fully assess the spatial and temporal occurrence of EOC in groundwater.

3. While subsurface transport may attenuate a large proportion of EOCs, in some instances groundwaters may continue to be a source of EOC for decades as a result of long 
groundwater residence times, low microbial populations and redox controls in the saturated zone. In the coming decades, more of these EOCs are likely to have drinking water standards, environmental quality standards and/or groundwater threshold values defined, and so a better understanding of the spatial and temporal variation remains a priority. This review has highlighted the fact that degradates are often found more frequently and in greater concentrations compared to parent compounds and reinforces the need to monitor and regulate for degradates of EOCs as well as parent compounds.

4. Research is needed to assess the importance of different sources and transport processes, as well as contaminant physicochemical properties, which combine to control EOC occurrence in groundwater. There is currently a lack of information regarding sorption processes on geological material from the unsaturated and saturated zone. Both field and modelling studies are needed to develop our understanding of the fate of EOC in the unsaturated zone. As yet there has been little attempt to understand the importance of largescale hydrogeological processes or redox controls on the occurrence and fate of EOCs in groundwater. Colloidal transport may be an important pathway for EOC within the subsurface, allowing EOCs to be transported further and faster than in the dissolved phase. The fate of EOCs in the hyporheic zone is as yet poorly understood.

5. The use of EOCs in groundwater as novel tracers for waste water sources is a developing research area. This may have particular value in elucidating nearby sources of groundwater pollution due to the large attenuation/dilution potential of groundwater systems.

\section{Acknowledgements}

The authors thank the Carnot Institute at BRGM (project no. 2010-28) and the BGS Groundwater Science programme for funding this work. Benjamin Lopez, BRGM, is thanked for helping to collate EOC occurrence data in Europe. BGS authors publish with the permission of the Executive Director of the BGS (Natural Environment Research Council). 


\section{Supplementary material}

Supplementary information on reviewed studies can be found in Table S1:

\section{References}

Adler, P., Steger-Hartmann, T.H., Kalbfus, W., 2001. Vorkommen natürlicher und synthetischer östrogener Steroide in Wässern des süd- und mitteldeutschen Raumes. Acta Hydrochimica et Hydrobiologica 29, 227-241.

Ahel, M., Jelicic, I., 2000. Occurrence of phenazone analgesics in landfill-leachate polluted groundwater. In: Keith, L.H., Needham, L.L., Jones-Lepp, T.L. (Eds.), Issues in the Analysis of Environmental Endocrine Disruptors, Proc. ACS Symp. vol. 40 (1), pp. 109-111. Washington, DC.

Ahel, M., Mikac, N., Cosovic, B., Prohic, E., Soukup, V., 1998. The impact of contamination from a municipal solid waste landfill (Zagreb, Croatia) on underlying soil. Water Science and Technology 37, 203-210.

Alemaw, B.F., Shemang, E.M., Chaoka, T.R., 2004. Assessment of groundwater pollution vulnerability and modelling of the Kanye wellfield in SE Botswana - a GIS approach. Physics and Chemistry of the Earth, Parts A/B/C 29, 1125-1128.

Alvarez, P.J.J., Illman, W.A., 2006. Bioremediation and Natural Attenuation. Wiley, Hoboken, NJ, p 577. 
Banzhaf, S., Krein, A., Scheytt, T., 2011. Investigative approaches to determine exchange processes in the hyporheic zone of a low permeability riverbank. Hydrogeology Journal 19, $591-601$.

Barber, L.B., Keefe, S.H., LeBlanc, D.R., Bradley, P.M., Chapelle, F.H., Meyer, M.T., Loftin, K.A., Kolpin, D.W., Rubio, F., 2009. Fate of sulfamethoxazole, 4- nonylphenol, and 17bestradiol in ground water contaminated by wastewater treatment plant effluent. Environmental Science and Technology 43, 4843-4850.

Barnes, K. K.,Christenson, S. C., Koplin, D. W.; Focazio, M., Furlong, E. T., Zaugg, S. D., Meyer, M. T., Barber, L. B., 2004. Pharmaceuticals and other organic waste water. contaminants within a leachate plume down gradient of a municipal landfill. Ground Water Monitoring and Remediation 24, 119-126.

Barnes, K., Kolpin, D., Furlong, E., Zaugg, S., Meyer, M., Barber, L., 2008. A national reconnaissance of pharmaceuticals and other organic wastewater contaminants in the United States I. Groundwater, Science of the Total Environment 402, 192-200.

Bartelt-Hunt, S., Snow, D.D., Damon-Powell, T., Miesbach, D., 2010. Occurrence of steroid hormones and antibiotic in shallow groundwater impacted by livestock waste control facilities. Journal of Contaminant Hydrology 123, 94-103.

Benotti, M.J., 2006. Occurrence and fate of pharmaceuticals in wastewater-impacted environments using HPLC-ToF-MS. Ph.D. diss., Coastal Oceanography, Stony Brook University, Stoney Brook, New York. 
Benotti, M.J., Bronawell, B.J., 2009. Microbial degradation of pharmaceuticals in esturine and coastal sewawater. Environmental Pollution 157, 994-1002.

Benotti, M.J., Trenholm, R.A., Vanderford, B.J., Holady, J.C., Stanford, B.D., Snyder, S.A., 2009. Pharmaceuticals and endocrine disrupting compounds in U.S. drinking water.

Environmental Science and Technology 43, 597-603.

Besse, J.-P., Garric, J., 2008. Human pharmaceuticals in surface waters. Implementation of a prioritization methodology and application to the French situation. Toxicology Letters 176, 104123.

Bouwer, H., 2002. Artificial recharge of groundwater: hydrogeology and engineering. Hydrogeology Journal 10, 121-142.

Bradford, S. A., Segal, E., Zheng, W., Wang, Q., Hutchins, S. R., 2008. Reuse of Concentrated Animal Feeding Operation Wastewater on Agricultural Lands. Journal of Environmental Quality 35, 97-115.

Brooks, B.W., Huggett, D.B., Boxall, A.B.A., 2009. Pharmaceuticals and personal care products: research needs for the next decade. Environmental Toxicology and Chemistry, 28, 2469-2472.

Bruchet, A., Hochereau, C., Picard, C., Decottignies, V., Rodrigues, J.M., Janex-Habibi, M.L., 2005. Analysis of drugs and personal care products in French source and drinking 
waters: the analytical challenge and examples of application. Water Science and Technology $52,53-61$.

Buerge, I.J., Poiger, T., Muller, M.D., Buser, H.-R., 2003. Caffeine, an anthropogenic marker for wastewater contamination of surface waters. Environmental Science and Technology 37, 691-700.

Buerge, I.J., Kahle, M., Buser, H.-R., Muller, M.D., Poiger, T., 2008. Nicotine derivatives in wastewater and surface waters: application as chemical markers for domestic wastewater. Environmental Science and Technology 42, 6354-6360.

Buerge, I. J., Buser, H.-R., Kahle, M., Müller, M. D., Poiger, T., 2009. Ubiquitous occurrence of the artificial sweetener acesulfame in the aquatic environment: an ideal chemical marker of domestic wastewater in groundwater. Environmental Science and Technology 43, 4381-4385.

Buerge, I.J., Keller, M., Buser, H-R, Müller, M. D, Poiger, T., 2011. Saccharin and Other Artificial Sweeteners in Soils: Estimated Inputs from Agriculture and Households, Degradation, and Leaching to Groundwater. Environmental Science and Technology 45, 615621.

Burke, V., Duennbier, U., Massmann, G., 2011. Laboratory experiments on redox-sensitivity of organic trace pollutants in groundwater. Geophysical Research Abstracts, 13, EGU20119821-1, EGU General Assembly 2011. 
Busenberg, E., Plummer, L.N., 1992. Use of chloroflurocarbons (CCl3F and CCl2F2) as hydrologic tracers and age dating tools: the alluvium and terrace system of central Oklahoma. Water Resources Research 28, 2257-83.

Buser, H.R., T. Poiger., M.D. Muller., 1999. Occurrence and environmental behavior of the chiral pharmaceutical drug ibuprofen in surface waters and in wastewater. Environmental Science and Technology 33, 2529-2535.

Buszka, P. M., Yeskis, D. J., Kolpin, D. W., Furlong, E. T., Zaugg, S. D., Meyer M. T., 2009. Waste-Indicator and Pharmaceutical Compounds in Landfill-Leachate-Affected Ground Water near Elkhart, Indiana, 2000-2002. Bulletin of Environ Contamination and Toxicology $82,653-659$.

Cabeza, Y., Candela, L., Teijón, J., Tamoh, K., 2011. Presence of Pharmaceuticals, Personal Care Products, and priority substances (2008/105EU) in groundwater (Llobregat delta, Barcelona, Spain). Geophysical Research Abstracts Vol. 13, EGU2011-3524-1, 2011, EGU General Assembly 2011.

Caliman, F.A., Gavirilescu, M., 2009. Pharmaceuticals, personal care products and endocrine disrupting agents in the environment - a review. Clean 37, 277-303.

Carrara, C., Ptacek, C.J., Robertson, W.D., Blowes, D.W., Moncur, M.C., Sverko, E., Backus, S1., 2007. Fate of pharmaceutical and trace organic compounds in three septic systems plumes, Ontario, Canada. Environmental Science and Technology 42, 2805-2811. 
Casey, F. X. M., Hakk, H., Simunek, J., Larsen, G. L., 2004. Fate and Transport of Testosterone in Agricultural Soils. Environmental Science and Technology 38, 790-798.

Celiz, M.D., Tso, J., Aga, D.S., 2009. Pharmaceutical metabolites in the environment: analytical challenges and ecological risks. Environmental Toxicology and Chemistry 28, $2473-2484$

Chen, F., Ying, G-G., Kong, L-X., Wang, L., Zhao, J-L., Zhou, L-J., Zhang, L-J., 2011. Distribution and accumulation of endocrine-disrupting chemicals and pharmaceuticals in wastewater irrigated soils in Hebei, China. Environmental Pollution 159, 1490-1498.

Chen, C.Y., Wen, T.Y., Wang, G.S., Cheng, H.W., Lin, Y.H., Lien, G.W., 2007. Determining estrogenic steroids in Taipei waters and removal in drinking water treatment using high-flow solid-phase extraction and liquid chromatography/tandem mass spectrometry. Science of the Total Environment 378, 352-365.

Chomycia, J.C., Hernes, P.J., Harter, T.H., Bergamaschi, B.A., 2008. Land Management Impacts on Dairy-Derived Dissolved Organic Carbon in Ground Water. Journal of Environmental Quality 37, 333-343.

Christensen, T. H., Kjeldsen, P., Albrechtsen, H. J., Heron, G., Nielsen, P. H., Bjerg, P. L., Holm, P. E., 1992. Attenuation of landfill leachate pollutants in aquifers. Critical Reviews in: Environmental Science and Technology 24, 119-202. 
Clara, M., Strenn, B., Kreuzinger, N., 2004. Carbamazepine as a possible anthropogenic marker in the aquatic environment : investigation on the behavior of carbamazepine in wastewater treatment during groundwater infiltration. Water Research 38, 947-954.

Clarke, B.O., Smith, S.R., 2011. Review of 'emerging' organic contaminants in biosolids and assessment of international research priorities for the agricultural use of biosolids. Environment International 37, 226-247.

Cordy, G.E., Duran, N.L., Bouwer, H., Rice, R.C., Furlong, E.T., Zaugg, S.D., Meyer, M.T., Barber, L.B., Kolpin, D.W., 2004. Do pharmaceuticals, pathogens, and other organic waste water compounds persist when waste water is used for recharge? Ground Water Monitoring and Remediation 24, 58-69.

Covaci, A., Gheorghe, A., Hulea, O., Schepens, P., 2006. Levels and distribution of organochlorine pesticides, polychlorinated biphenyls and polybrominated diphenyl ethers in sediments and biota from the Danube Delta, Romania. Environmental Pollution 140, 136-149.

Crane, M., Watts, C., Boucard, T., 2006. Chronic aquatic environmental risks from exposure to human pharmaceuticals. Science of the Total Environment 367, 23-41.

Cronin, M.T.D., Walker, J.D., Jaworska, J.S., Comber, M.H.I., Watts, C.D., Worth, A.P., 2003. Use of QSARs in international decision-making frameworks to predict ecologic effects and environmental fate of chemical substances. Environmental Health Perspectives 111, 1376-90. 
Daher, W., Pistre, S., Kneppers, A., Bakalowicz, M., Najem, W., 2011. Karst and artificial recharge: Theoretical and practical problems A preliminary approach to artificial recharge assessment. Journal of Hydrology 408, 189-202

Darling, G.W., Gooddy, D.C., MacDonald, A.M., Morris, B.L. The practicalities of using CFCS and SF6 for groundwater dating and tracing. Applied Geochemistry (in press).

Daughton, C.G., Ternes T.A., 1999. Pharmaceuticals and Personal Care Products in the Environment: Agents of Subtle Change? Environmental Health Perspectives 107, 907-938.

Díaz-Cruz, M. S., Barceló, D., 2008. Trace organic chemicals contamination in ground water recharge. Chemosphere 72, 333-342.

Dickenson, E.R.V., Snyder, S.A., Sedlak, D.L., Drewes, J.E., 2011. Indicator compounds for assessment of wastewater effluent contributions to flow and water quality. Water Research $45,1199-1212$.

Domènech, X., Ribera, M., Peral, J., 2011. Assessment of Pharmaceuticals Fate in a Model Environment. Water, Air, \& Soil Pollution 218, 413-422.

Drewes, J.E., Heberer, T. Rauch, T., Reddersen K., 2003. Fate of pharmaceuticals during groundwater recharge. Ground Water Monitoring and Remediation 23, 64-72.

Drewes, J.E., Heberer, T., Reddersen, K., 2002, Fate of pharmaceuticals during indirect potable reuse, Water Science and Technology 46, 73-80. 
Drewes J.E. 2009. Ground water replenishment with recycled water - water quality improvements during managed aquifer recharge. Ground Water 47, 502-505.

Eckel, W.P., Ross, B., Isensee, R.K., 1993. Pentobarbital found in ground water. Ground Water 5, 801-804.

Einsiedl, F., Radke, M., Maloszewski, P., 2010. Occurrence and transport of pharmaceuticals in a karst groundwater system affected by domestic wastewater treatment plants. Journal of Contaminant Hydrology 117, 26-36.

Ellis, J.B. 2006. Pharmaceutical and personal care products (PPCPs) in urban receiving waters. Environmental Pollution 144, 184-189.

Environment Agency (EA), 2007. Investigation of PFOS and other perfluorochemicals in groundwater and surface water in England and Wales. Environment Agency, Bristol, UK.

Environment Agency (EA), 2011. Important environmental infomation about using Baycox®. Last accessed July 2011. http://publications.environmentagency.gov.uk/PDF/GEHO0506BKUZ-B-E.pdf.

Environmental Data Summary (ENDS), Report 439, August 2011, p 51. 
European Communities, 2008. Tris (2-Chloroethyl) phosphate, TCEP: Summary risk assessment report. Last accessed in June 2011:http://ecb.jrc.ec.europa.eu/documents/ExistingChemicals/RISK_ASSESSMENT/SUMMARY/tcepsum068.pdf

European Commission (EC), 2000. Directive 2000/60/EC of the European Parliament and of the Council of 23 October 2000 establishing a framework for Community action in the field of water policy. Official Journal of the European Union L327/1, 22/12/2000.

European Commission (EC), 2006. Directive 2006/118/EC of the European Parliament and the Council of 12th of December 2006 on the protection of ground water against pollution and deterioration. Official Journal of the European Union L 372/19, 27/12/2006.

European Commission (EC), 2008. Directive 2008/105/EC of the European parliament and of the council on environmental quality standards in the field of water policy. Official Journal of the European Union L 348/84, 24/12/2008.

European Commission (EC), 2011. Sewage sludge. European Commission, Brussels. Accessed September 2011.< http://ec.europa.eu/environment/waste/sludge/index.htm>.

Faille, J., 2010. Vulnérabilité des nappes d'eau souterraine aux pollutions médicamenteuses: aquifer vulnerability to drug pollution [a literature review]. Masters dissertation, Lille polytechnic. (Abstract in english), p 19. 
Fawell, J.K., Sheahan, D., James, H.A., Hurst, M., Scott, S., 2001. Oestrogens and oestrogenic activity in raw and treated water in Severn Trent Water. Water Research 35, $1240-1244$.

Fawell, J. 2010. Proposed Drinking Water Directive update. Emerging Contaminants and Advanced Treatment Technologies, March 23 2010. London, CIWEM Drinking Water Conference.

Federal Drug Agency (FDA)., 2011. http://www.fda.gov/Drugs/default.htm, (Accessed May 2011)

Fent, K., Weston, A.A., Caminada, D., 2006. Ecotoxicology of human pharmaceuticals. Aquatic Toxicology 76, 122-159.

Fernandez, C.C., Martinez, J.J., Candela, L., Mazo, E.G., 2011. Presence of synthetic surfactants in groundwater derived by sewage contamination. Geophysical Research Abstracts, Vol. 13, EGU2011-4966, 2011, EGU General Assembly 2011.

Focazio, M.J., Kolpin, D.W., Barnes, K.K., Furlong, E.T., Meyer, M.T., Zaugg, S.D., Barber, L.B., Thurman, M.E., 2008. A national reconnaissance for pharmaceuticals and other organic wastewater contaminants in the United States - ii) Untreated drinking water sources. Science of the Total Environment 402, 201-216. 
Foster, S., Lawrence, A., Morris, B., 1998. Groundwater in Urban Development: Assessing Management Needs and Formulating Policy Strategies. World Bank Technical Paper No. 390. Washington DC.

Fram, M.S., Belitz, K., 2011. Occurrence and concentrations of pharmaceutical compounds in groundwater used for public drinking-water supply in California. Science of the Total Environment 409, 3049-3417.

Gale, I., Dillon, P., 2005. Strategies for Managed Aquifer Recharge (MAR) in Semiarid Areas. UNESCO-IHP, Paris.

Gasser, G., Rona, M., Voloshenko, A., Shelkov, R., Tal, N., Pankratov, I., Elhanany, S., Lev, O., 2010. Quantitative Evaluation of Tracers for Quantification of Wastewater Contamination of Potable Water Sources. Environmental Science and Technology 44, 3919-3925.

Godfrey, E., Woessner, W. W., Benotti, M. J., 2007. Pharmaceuticals in on-site sewage effluent and ground water, Western Montana. Ground Water 45, 263-271.

Gourcy, L., Baran, N., Vittecoq, B., 2009. Improving the knowledge of pesticide and nitrate transfer processes using age-dating tools $(\mathrm{CFC}, \mathrm{SF} 6,3 \mathrm{H})$ in a volcanic island (Martinique, French West Indies). Journal of Contaminant Hydrology 108,107-117.

Glassmeyer, S.T., Furlong, E.T., Kolpin, D.W., Cahill, J.D., Zaugg, S.D., Werner, S.L., Meyer, M.T., Kryak, D.D., 2005. Transport of chemical and microbial contaminants from 
known wastewater discharges: potential for use as indicators of human fecal contamination. Environmental Science and Technology 39, 5157-5169.

Grünheid, S., Amy, G., Jekel, M., 2005. Removal of bulk dissolved organic carbon (DOC) and trace organic compounds by bank filtration and artificial recharge, Water Research 39, $3219-3228$

Gutiérrez, I.R., Watanabe, N., Harter T., Glaser B., Radke, M., 2010. Effect of sulfonamide antibiotics on microbial diversity and activity in a Californian Mollic Haploxeralf. Journal of Soils and Sediments 10, 537-544.

Halling- Sørensen, B., Neilsen, S.N., Lanzky, P.E., Ingerslev, F, Lüthøft, H.C.H., Jørgensen, S.E., 1998. Occurrence, Fate and effects of pharmaceutical substances in the environment - a review. Chemosphere 36, 357-393.

Hansch, C., Leo, A., Hoekman, D.,1995. Exploring QSAR: Hydrophobic, Electronic, and Steric Constants, Washington DC, American Chemical Society, 17p.

Heberer, T. 2002. Tracking persistent pharmaceutical residues from municipal sewage to drinking water. Journal of Hydrology 266, 175- 189.

Heberer, T., Adam, M., 2004. Transport and attenuation of pharmaceutical residues during artificial ground water replenishment, Environmental Chemistry 1, 22-25. 
Heberer, T., Dünnbier, U., Reilich C., Stan, H.J., 1997. Detection of drugs and drug metabolites in ground water samples of a drinking water treatment plant, Fresenius Environmental Bulletin 6, 438-443.

Heberer, T., Fuhrmann, B., Schmidt-Baunler, K., Tsips, D., Koutsouba, , Hiskia, V., 2000. Occurrence of pharmaceuticals residues in sewage, river, ground and drinking water in Greece and Germany. Symposia: Issues in the analysis of environmental endocrine disruptors, ACS, San Francisco.

Heberer, T., Mechlinski, A., Fanck, B., Knappe, A., Massmann, G., Pekdeger, A., Fritz, B., 2004. Field studies on the fate and transport of pharmaceutical residues in bank filtration. Ground Water Monitoring and Remediation 24, 70-77.

Heberer, T., Schmidt-Baumler, K., Stan, H. J., 1998. Occurrence and distribution of organic contaminants in the aquatic system in Berlin. Part 1: Drug residues and other polar contaminants in Berlin surface and groundwater. Acta Hydrochimica et Hydrobiologica 26, $272-278$.

Helsel, D.R., 2005. Nondetects And Data Analysis: Statistics for censored environmental data. John Wiley and Sons, New York. 250p.

Hillebrand, O., Nödler, K., Geyer, T., Sauter, M., 2011. Application of caffeine as indicator for the quantification of recharging wastewater in karst systems - A case study. Geophysical Research Abstracts, Vol. 13, EGU2011-3377, 2011, EGU General Assembly 2011. 
Hilton, M., Thomas, K.V., Ashton, D., 2003. Targeted monitoring programme for pharmaceuticals in the aquatic environment. UK Environment Agency R\&D Technical Report P6-012/6, Environment Agency, UK.

Hinkle, S.R., Weick, R.J., Johnson, J.M., Cahill, J.D., Smith, S.G., Rich, B.J., 2005, Organic wastewater compounds, pharmaceuticals, and coliphage in ground water receiving discharge from onsite wastewater treatment systems near La Pine, Oregon-Occurrence and implications for transport: U.S. Geological Survey Scientific Investigations Report 2005$5055,98 \mathrm{p}$

Hirsch, R., Ternes, T., Haberer, K., Kratz, K-L., 1999. Occurrence of antibiotics in the aquatic environment. Science of the Total Environment 225, 109-118.

Hoai, P.M., Ngoc, N.T., Minh, N.H., Viet, P.H., Berg, M., Alder, A., Giger., 2010. Recent levels of organochlorine pesticides and polychlorinated biphenyls in sediments of the sewer system in Hanoi, Vietnam. Environmental Pollution 158, 913-920.

Hohenblum, P., Gras, O., Moche, W., Scharf, S., Lorbeer, G., 2004. Monitoring of selected estrogenic hormones and industrial chemicals in groundwaters and surface waters in Austria. Science of the Total Environment 333, 185-193.

Holm, J.V., Rügge, K., Bjerg, P.L., Christensen, H., 1995. Occurrence and distribution of pharmaceutical organic compounds in the groundwater downgradient of a landfill (Grindsted, Denmark). Environmental Science and Technology 28, 1415-1420. 
Houtman, C., 2010. Emerging contaminants in surface waters and their relevance for the production of drinking water in Europe. Journal of Integrative Environmental Science 7, 271295.

Hu, Xiangang., Zhou, Q., Luo, Y., 2010. Occurrence and source analysis of typical veterinary antibiotics in manure, soil, vegetables and groundwater from organic vegetable bases, northern China. Environmental Pollution 158, 2992-2998.

Huschek, G., Hansen P.D., Maurer, H H., Krengel, D., Kayser, A., 2004. Environmental risk assessment of medicinal products for human use according to European Commission recommendations. Environmental Toxicology19, 226-240.

Jaworska J., Dimitrov, S., Nikolova, N., Mekenyan, O., 2002. Probabilistic assessment of biodegradability based on metabolic pathways: CATABOL System. SAR QSAR. Environmental Research 13, 307-323.

Johnson, A.C., Hughes, C.D., Williams, R.J., Chilton, P.J., 1998. Potential for aerobic isoproturon biodegradation and sorption in the unsaturated and saturated zones of a chalk aquifer. Journal of Contaminant Hydrology 30, 281-297.

Jones, O.A., Lester, J.N., Voulvoulis, N., 2005. Pharmaceutical: a threat to drinking water? Trends in Biotechnology 23, 163-167. 
Juhler, R.K., Felding, G., 2003. Monitoring methyl tertiary butyl ether (MTBE) and other organic micropollutants in groundwater: Results from the Danish National Monitoring Program. Water, Air, \& Soil Pollution 149, 145-161.

Katz, B.G., Griffin, D.W., Davis, J.H., 2009. Groundwater quality impacts from land application of treated municipal wastewater in a large karstic spring basin: Chemical and micbiological indicators. Science of the Total Environment 407, 2872-2886.

Knoth, W., Mann, W., Meyer, R., Nebhuth, J., 2003. Brominated Diphenyl Ether in Indoor Dust. Organohalogen Compounds 61, 207-210.

Kohler, H-P.E., Angst, W., Giger, W., Kanz, C., Müller, S., Suter, M.J.F., 1997.

Environmental fate of chiral pollutants and the necessity of considering stereochemistry. Chimia 51, 947-951.

Kolpin, D.W., Barbash, J.E., Gilliom, R.J., 1998. Occurrence of pesticides in shallow groundwater of the UnitedStates: Initial results from the National Water-Quality Assessment Program. Environmental Science and Technology 32, 558-566.

Kolpin, D.W., Furlong, E.T., Meyer,M.T., Thurman, E.M., Zaugg, S.D., Barber, L.B., Buxton, H.T., 2002. Pharmaceuticals, hormones, and other organic wastewater contaminants in US streams, 1999-2000: a national reconnaissance, Environmental Science and Technology 36, 1202-1211. 
Kolpin, D. W., Thurman, E. M., Linhart, S. M., 2000. Finding minimal herbicide concentrations in ground water? Try looking for their degradates. Science of the Total Environment 248, 115-122.

Kolodziej, E.P., Harter, T., Sedlak, D.L., 2004. Dairy wastewater, aquaculture, and spawning fish a sources of steroid hormones in the aquatic environment. Environmental Science and Technology 38, 6377-6384.

Kreuzinger, N., Clara, M., Strenn, B., Vogel, B., 2004. Investigation on the behaviour of selected pharmaceuticals in the groundwater after infiltration of treated wastewater. Water Science and Technology 50, 221-228.

Kuch, M.H., Ballschmiter, K., 2001. Determination of endocrinedisrupting phenolic compounds and estrogens in surface and drinking water by HRGC-(NCI)-MS in the pictogram per liter range. Environmental Science and Technology 35, 3201-3206.

Kümmerer, K, 2001. Drugs in the environment: emission of drugs, diagnostic aids and disinfectants into wastewater by hospitals in relation to other sources - a review. Chemosphere, 45, 957-969.

Kümmerer, K, 2008. Pharmaceuticals in the environment: sources, fate, effects and risks. Springer-Verlag, 521p 
Kümmerer, K, 2009. The presence of pharmaceuticals in the environment due to human usepresent knowledge and future challenges. Journal of Environmental Management 90, 23542366.

Kuster, M., Díaz-Cruz, S., Rosell, M., Lopez de Alda, M., Barceló, D., 2010. Fate of selected pesticides, estrogens, progestogens and volatile organic compounds during artificial aquifer recharge using surface waters. Chemosphere 79, 880-886.

Kutcha, S.L., Cessna, A.J., 2009. Lincomycin and spectinomycin concentrations in liquid swine manure and their persistence during simulated manure storage. Archives of Environmental Contamination and Toxicology 57, 1-10.

Lapworth, D.J., Gooddy, D.C., 2006. Source and persistence of pesticides in a semi-confined chalk aquifer of southeast England, Environmental Pollution 144, 1031-1044.

Lapworth, D.J., Gooddy, D.C., Allen, D., Old, G.H., 2009. Understanding groundwater, surface water and hyporheic zone biogeochemical processes in a Chalk catchment using fluorescence properties of dissolved and colloidal organic matter. Journal of Geophysical Research 114, G00F02. 10, pp. 10.1029/2009JG000921.

Laws, B.V., Dickenson, E.R.V., Johnson, T.A., Snyder, S.A., Drewes, J.E., 2011. Attenuation of contaminants of emerging concern during surface-spreading aquifer recharge. Science of the Total Environment 409, 1087-1094. 
Leister, D.L., Baker, J.E., 1994. Atmospheric deposition of organic contaminants to the Chesapeake bay. Atmospheric Environment 28, 1499-1520.

Leistra, M., Boesten. J.J.T.I., 1989. Pesticide contamination of groundwater in Western Europe. Agriculture, Ecosystems \& Environment 26, 369-389.

Lev, O., Gasser, G., Rona, M., Pankratov, I., 2011. Quantitative evaluation of tracers for quantification of wastewater contamination of potable water sources. Geophysical Research Abstracts, 13, EGU2011-5882, 2011, EGU General Assembly 2011.

Lewandowski, J., Putschew,A., Schwesig, D., Neumann,C., Radke, M., 2011. Fate of organic micropollutants in the hyporheic zone of a eutrophic lowland stream: Results of a preliminary field study. Science of the Total Environment 409, 1824-1835.

Lindsey, M.E., Meyer, M., Thurman, E.M., 2001. Analysis of trace levels of sulfinamide and tetracycline antimicrobials in groundwater and surface water using solid-phase extraction and liquid chromatography/mass spectroscopy. Analytical Chemistry 73, 4640-4646.

Loos, R., Locoro, G., Comero, S., Contini, S., Schwesig, D.,Werres, F., Balsaa, P., Gans, O., Weiss, S., Blaha, L., Bolchi, M., Gawlik, B.M., 2010a. Pan-European survey on the occurrence of selected polar organic persistent pollutants in ground water. Water Research 44, 4115-4126.

Maeng, S.K., E. Ameda, A., Sharma, S.K., Grützmacher, G., Amy, G., 2010. Organic micropollutant removal from wastewater effluent-impacted drinking water sources during bank filtration and artificial recharge, Water Research 44, 4003-4014. 
Maeng, S.K., Sharma, S.K., Lekkerkerker-Teunissen, K., Amy, G., 2011. Occurrence and fate of bulk organic matter and pharmaceutically active compounds in managed aquifer recharge: A review. Water Research 45, 3015-3033.

Mansell, J., Drewes, J.E., 2004. Fate of steroidal hormones during soil-aquifer treatment. Ground Water Monitoring and Remediation 24, 94-101.

Mckinney, C.W., Loftin, K.A., Meyer, M.T., Davis, J.G., Pruden, A., 2010. Tet and sul Antibiotic resistance genes inlivestock lagoons of various operation type, configuration, and abiotic occurrence. Environmental Science and Technology 44, 6102-6109.

Meinen, V.J., McKay, T.W., 1987. Product chemistry - Physical and chemical characteristics of diethyltoluamide including: water solubility, octanol/water partition coefficient and miscibility. McLaughlin Gormley King Co. DPR Vol. 50191-50192, Rec. No. 91584.

de Mes, T., Zeeman, G., Lettinga, G., 2005. Occurrence and fate of estrone, 17b-estradiol and 17a-ethynylestradiol in STPs for domestic wastewater. Reviews in Environmental Science and Bio/Technology 4, 275-311.

Miller, K J., Meek, J., 2006. Helena Valley ground water: pharmaceuticals, personal care products, endocrine disruptors (PPCPs) and microbial indicators of faecal contamination. Montana Bureau of Mines and Geology, Open File Report 532. 
Morris, B., Cunningham, J., 2008. Suburbanisation of important aquifers in England and Wales: estimating its current extent. Water and Environment Journal 22, 88-99.

Morris, D.L., Darling, W.G., Gooddy, D.C., Litvak, R.G., Neumann, I., Nemaltseva, E.J., Poddubnaia, I., 2005. Assessing the extent of induced leakage to an urban aquifer using environmental tracers: an example from Bishkek, capital of Kyrgyzstan, Central Asis. Hydrogeology Journal 14, 225-243.

Mueller, B., Scheytt, T., Asbrand, M., 2011. Quantification of exchange rates between groundwater and surface water applying pharmaceutical compounds - the Nuthegraban case. Geophysical Research Abstracts, 13, EGU2011-2257, 2011 EGU General Assembly 2011.

Murray, K.E., Thomas, S.M., Bodour, A.A., 2010. Prioritizing research for trace pollutants and emerging contaminants in the freshwater environment. Environmental Pollution 158, $3462-3471$

Musolff, A., Leschik, S., Moder, M, Strauch, G., Reinstorf, F., Schirmer, M., 2009. Temporal and spatial patterns of micropollutants in urban receiving waters. Environmental Pollution 157, 3069-3077.

Nakada, N., Kiri, K., Shinohara, H., Harada, A., Kuroda, K., Takizawa, S., Takada, H., 2008. Evaluation of pharmaceuticals and personal care products as water-soluble molecular markers of sewage, Environmental Science and Technology 42, 6347-6353. 
NAQUA, 2009. BAFU 2009: Ergebnisse der Grundwasserbeobachtung Schweiz (NAQUA).

Zustand und Entwicklung 2004-2006. Umwelt-Zustand Nr. 0903. Bundesamt für Umwelt, Bern. 144 S. http://www.bafu.admin.ch/publikationen/publikation/01021/index.html?lang=de

Ni, N., Sanghvi, T., Yalkowsky, S.H., 2002. Independence of the product of solubility and distribution coefficient of pH. Pharmaceutical Research 19, 1862-1866.

Nowak, K.M., Miltner, A., Gehre, M.,Schäffer, A., Kästner, M., 2011. Formation and fate of bound residues from mircrobial biomass during 2,4-D degradation in soil. Environmental Science and Technology 45, 999-1006.

Olshansky, Y., Polubesova, T., Vetter, W., Chefetz, B., 2011. Sorption-desorption behavior of polybrominated diphenyl ethers in soils. Environnemental Pollution 159, 2375-2379.

Oppel, J., Broll, G., Loffler, D., Meller, M., Rombke, J., Ternes, T., 2004. Leaching behaviour of pharmaceuticals in soil-testing systems: a part of an environmental risk assessment for groundwater protection. Science of the Total Environment 328, 265- 273.

Osenbruck, K., Gläser, H-R, Knoller, K., Weise, S.M., Moder, M., Wennrich, R., Schirmer, M., Reinstorf, F., Busch, W., Strauch, G., 2007. Sources and transport of selected organic micropollutants in urban groundwater underlying the city of Halle (Saale), Germany. Water Research 41, 3259-3270. 
Pal, A., Gin, A.Y-C., Reinhard, M., 2010. Impacts of emerging organic contaminants on freshwater resources: Review of recent occurrences, sources, fate and effects. Science of the Total Environment 408, 6062-6069.

Pecoranio, G., Scalici, L., Avellone, G., Ceraulo, L., Favara, R, Candela, E.G., Provenzano, M.C., Scaletta, C., 2008. Distribution of volatile organic compounds in Sicilian groundwaters analysed by head space-solid phase micro extraction coupled with gas chromatography mass spectrometry (SPME/GC/MS). Water Research 43, 3563-3577.

Petrovic, M., Barceló, D., 2006. Application of liquid chromatography/quadruple time-offlight mass spectrometry (LC-QqTOF-MS) in the environmental analysis. Journal of mass spectometry $41,1259-1267$.

Pruden, A., Pei, R., Storteboom, H., Carlson, K. H., 2006. Antibiotic resistance genes as emerging contaminants: Studies in northern Colorado. Environmental Science and Technology 40, 7445-7450.

Putschew, A., Wischnack, S., Jekel, M., 2000. Occurrence of triiodinated X-ray contrast agents in the aquatic environment. Science of the Total Environment 255, 129-134.

Rabiet, M., Togola, A., Brissaud, F., Seidel, J-L, Budzinski, H., Elbaz-Poulichet, F., 2006. Consequences of treated water recycling as regards pharmaceuticals and drugs in surface and ground waters of a medium-sized Mediterranean catchment. Environmental Science and Technology 40, 5282-5288. 
Reddersen, K., Heberer, T., Dünnbier, U., 2002. Identification and significance of phanazone drugs and their metabolites in ground- and drinking water. Chemosphere 49, 539-544.

Richardson, S.D., 2009. Water analysis: emerging contaminants and current issues. Analytical Chemistry $81,4645-4677$.

Richardson, S.D., Ternes, T.A., 2011. Water analysis: emerging contaminants and current issues. Analytical Chemistry 83, 4614-4648.

Ritter, W.F., 1990. Pesticide contamination of groundwater in the United States - A review. Journal of Environmental Science and Health, Part B: Pesticides, Food Contaminants and Agricultural Wastes 25, 1-29.

Rodriguez-Mozaz, S., Lopez de Alda, M., Barcelo, D., 2004. Monitoring of estrogens, pesticides and bisphenol $\mathrm{A}$ in natural waters and drinking water treatment plant by solid-phase extraction-liquid chromatography-mass spectrometry. Journal of Chromatography A 1045, $85-92$.

Rueedi, J., Cronin, A A., Morris, B., 2009. Estimation of sewer leakage to urban groundwater using depth-specific hydrochemistry. Water and Environment Journal 23, 134144. 
Sacher, F., Lange, F.T., Brauch, H-J., Blankenhorn, I., 2001. Pharmaceuticals in groundwaters Analytical methods and results of a monitoring program in Baden-Württemberg, Germany. Journal of Chromatography A 938, 199-210.

Sangster, J., 1997. Octanol-water partition coefficients: fundamentals and physical chemistry.: John Wiley \& Sons, Chichester, 170p.

Sarmah, A.K., Meyer, M.T., Boxall, A.B.A., 2006. A global perspective on the use, sales, exposure pathways, occurrence, fate and effects of veterinary antibiotics (Vas) in the environment. Chemosphere 65, 725-759.

Sassman, S.A., Lee, L.A., 2005. Sorption of Three Tetracyclines by Several Soils: Assessing the Role of $\mathrm{pH}$ and Cation Exchange. Environmetnal Science and Technology 39, 7452-7459.

Schaffer, M., Börnick, H., Licha, T., Nödler, K., Worch, E., 2011. Column experiments to simulate the transport of the basic beta-blocker atenolol in sandy aquifers under competitive conditions. Geophysical Research Abstracts, 13, EGU2011-3018, 2011, EGU General Assembly 2011.

Scheurer, M., Brauch, H. J., Lange, F. T. 2008. Analysis and occurrence of seven artificial sweeteners in German waste water and surface water and in soil aquifer treatment (SAT). Analytical and Bioanalytical Chemistry 42, 1585-1594.

Scheytt, T., Mersmann, P., Leidig, M., Pekdeger, A., Heberer, T., 2004. Transport of pharmaceutically active compounds in saturated laboratory columns. Ground Water 42, 767773. 
Scheytt, T., Mersmann, P., Lindstädt, R., Heberer, T., 2005. Determination of sorption coefficients of pharmaceutically active substances carbamazepine, diclofenac, and ibuprofen, in sandy sediments. Chemosphere 60, 245-253.

Scheytt, T., Müller, B., 2011. Trace compounds in groundwater as indicators for transport processes on the catchment scale. Geophysical Research Abstracts, 13, EGU2011-3528, EGU General Assembly 2011.

Schmid, P., Kohler, M., Gerecke, A.C., Gujer, E., Zennegg, M., Weolfensberger, M., 2003. Old sins throw long shadows - old and emerging persistent organic pollutants in the Swiss environment. Chimia 57, 509-513.

Schmidt, C.K., Lange, F.T., Brauch, H-J., Kühn, W., 2003. Experiences with riverbank filtration and infiltration in Germany. DVGW-Water Technology Center (TZW), pp17.

Schulz, M., Loffler, D., Wagner, M., Ternes, T. A., 2008. Transformation of the X-ray Contrast Medium Iopromide In Soil and Biological Wastewater Treatment. Environmental Science and Technology 42, 7207-7217.

Schwarzenbach, R.P., Escher, B.I., Fenner, K., Hofstetter, T.B., Johnson, C.A., v-Guten, U., Wehrli, B., 2006. Science 313, 1072-1077.

Sedlak, D.L., Pinkston, KE., 2001. Factors affecting the concentrations of pharmaceuticals released to the aquatic environment. Water Research 120, 56-64. 
Seiler, R.L., Zaugg, S.D., Thomas, J.M., Howcroft, D.L., 1999. Caffeine and pharmaceuticals as indicators of waste water contamination in wells. Ground Water 37, 405-410.

Semple, K.T., Doick, K.J., Wick, L.Y., Harms, H., 2007. Microbial interactions with organic contaminants in soil: definitions, processes and measurement. Environmental Pollution 150, $166-176$.

Shao, B., Han, H., Li, D., Ma, T., Tu, X., Wu, Y., 2007. Analysis of alkylphenol and bisphenol A in meat by accelerated solvent extraction and liquid chromatography with tandem mass spectroscopy. Food Chemistry 105, 1237-1241.

Shapiro, S.D., Busenberg, E., Focazio, M.J., Plummer, L.N., 2004. Historical trends in occurrence and atmospheric inputs of halogenated volatile organic compounds in untreated ground water used as a source of drinking water. Science of the Total Environment 321, 201217.

Shinohara, H., Murakami, M., Managaki, S., Kojima, S., Takada, H., Sato, N., Suzuki, Y., Nakada, N., 2006. Removal of water-soluble organic micro-pollutants by soil infiltration. Journal of Environmental Science 19, 435-444.

Shore, L.S., Shemesh, M., 2003. Naturally produced steroid hormones and their release into the environment. Pure and Applied Chemistry 75, 1859-1871. 
Snyder, S.A., Leising, J., Westerhoff, P., Yoon, Y., Mash, H., Vanderford, B., 2004. Biologial and physical attenuation of endocrine disruptors and pharmaceuticals: implications for water reuse. Ground Water Monitoring and Remediation 24, 108-118.

SRC. 2010. Interactive PhysProp database. Syracuse, New York: SRC Inc. Available from http://www.syrres.com/what-we-do/databaseforms.aspx?id=386

Srivastava, P., Sanders, S.M., Dane, J.H., Feng, Y., Basile, J., Barnett, M.O., 2009. Fate and transport of sulfadimethoxine and ormetoprim in two Southeastern United States soils. Vadose Zone Journal 8, 32-41.

Stan, H-J., Linkerhagner. M., 1992. Identification of 2-(4-Chlorphenoxy)-2-methyI-Propionis Acid in Groundwater with GC-AED and GC-MS, Vom Wasser 79, 75-88.

Stan, H-J., Heberer, T., Linkerhäigner, M., 1994. Occurrence of Clofibric Acid in the Aquatic System - Is the Use of Human Medical Care the Source of the Contamination of Surface, Ground and Drinking Water? - Vom Wasser 83, 57-68.

Stackelberg, P.E., Gibs, J., Furlong, E.T., Meyer, M.T., Zaugg, S.D., Lippincott, R.L., 2007. Efficiency of conventional drinking water- treatment processes in removal of pharmaceuticals and other organic compounds. Science of the Total Environment 377, 255-272.

Stolker, A.M.M., Niesing, W., Hogendoorn, E.A., Versteegh, J.F.M., Fuchs, R., Brinkman, U.A.T., 2004. Liquid chromatography with triplequadrupole or quadrupole-time of flight 
mass spectrometry for screening and confirmation of residues of pharmaceuticals in water. Analytical and Bioanalytical Chemistry 378, 955-963.

Stuart, M.E., Gooddy, D.C., Kinniburgh, D.G., Klinck, B.A., 2001. Trihalomethane Formation Potential: A Tool For Detecting Non-Specific Organic Groundwater Contamination. Urban Water 3, 197-208.

Stuart, M.E., Manamsa, K., Talbot, J.C., Crane, E.J., 2011. Emerging contaminants in groundwater. British Geological Survey Open Report, OR/11/013. 72pp.

Stuer-Lauridsen, F., 2005. Review of passive accumulation devices for monitoring organic micropollutants in the aquatic environment. Environmental Pollution 136, 503-524.

Swartz, W., C. H.; Reddy, S.; Benotti, M. J.; Yin, H. F.; Barber, L. B.; Brownawell, B. J.; Rudel, R. A., 2006. Steroid estrogens, nonylphenol ethoxylate metabolites, and other wastewater contaminants in groundwater affected by a residential septic system on Cape Cod, MA. Environmental Science and Technology 40, 4894-4902.

Teijon, G., Candela, L., Tamoh, K., Molina-Diaz, Fernandez-Alb, A.R., 2010. Occurrence of emerging contaminants, priority substances (2008/105/CE) and heavy metals intreated wastewater and groundwater at Depurbaix facility (Barcelona,Spain). Science of the Total Environment 408, 3584-3595. 
Ternes, T.A., Hirsch, R., 2000. Occurrence and behaviour of X-ray contrast media in sewage facilities and the aquatic environment, Environmental Science and Technology 34, 27412748.

Terry A.S., Carter A.D., Humphrey R.L., Capri E., Grua B., Panagopoulous A.C., PulidoBosch A and Kennedy S H., 2008. A monitoring programme for 1,3-dichloropropene and metabolites in groundwater in five EU countries. Pesticide Management Science 64, 923-932.

Togola, A., 2006. Présence et devenir des substances pharmaceutiques dans les écosystèmes aquatiques, http://grenet.drimm.u-bordeaux1.fr/pdf/2006/TOGOLA_ANNE_2006.pdf, 331p.

Thorne, P.S., 2007. Environmental Health Impacts of Concentrated Animal Feeding Operations: Anticipating Hazards - Searching for Solutions. Environmental Health Perspectives 115, 296-297.

Tracol, R., Duchemin, J., 2009. Evaluation de l'occurrence des résidus de médicaments dans unéchantillon de nappes souterraines vulnérables du bassin Seine Normandie utilisées pour laproduction d'eau destinée à la consommation humaine, 42p. Service santé-environment and Agence de eau Seine-Normadie. Last accessed June 2011. http://sigessn.brgm.fr/IMG/pdf/Medic_Pert_Endocr_synthese_052009.pdf

United States Environmental Protection Agency (USEPA), 2006. Edition of the Drinking Water Standards and Health Advisories. United States Environmental Protection Agency. 
[cited August 2010]. Available from

http://epa.gov/waterscience/criteria/drinking/dwstandards.pdf

Unold, M., Šimůnek, J., Kasteel, R., Groeneweg, J., Vereecken, H., 2009. Transport of manure-based applied sulfadiazine and its main transformation products in soil columns. Vadose Zone Journal 8, 677-689.

Verliefde, A., Cornelissen, E., Amy, G., vd Bruggen, B., v Dijk, H., 2007. Priority organic micropollutants in water sources in Flanders and the Netherlands and assessment of removal possibilities with nanofiltration. Environmental Pollution 146, 281-289.

Verstraeten, I.M., Fetterman, G.S., Meyer, M.T., Bullen, T., Sebree, S.K., 2005. Use of tracers and isotopes to evaluate vulnerability of water in domestic wells to septic waste. Ground Water Monitoring and Remediation 25, 107-117.

Villanneau, E.J., Saby, N.P.A., Marchant, B.P., Jolivet, C., Boulonne, L., Caria, G., Barriuso, E., Bispo, A., Briand, O., Arrouays, D., 2011. Which persistent organic pollutants can we map in soil using a large spacing systematic soil monitoring design? A case study in Northern France. Science of the Total Environment 409, 3719-3731.

de Voogt, P., Berger, U., de Coen, W., de Wolf, W., Heimstad, E., Mclachlan, M., van Leeuwen, S.,van Roon, A., 2006. PERFORCE perfluorinated organic compounds in the european environment. fp6-nest final report EU contract number 508967. 
Vulliet, E., Wiest, L., Baudot, R., Grenier-Loustalot, M. F., 2008. Multi-residue analysis of steroids at sub-ng/L levels in surface and ground-waters using liquid chromatography coupled to tandem mass spectrometry. Journal of Chromatography A 1210, 84-91.

Vulliet E., Cren-Olivé C., 2011. Screening of pharmaceuticals and hormones at the regional scale, in surface and groundwaters intended to human consumption, Environmental Pollution $159,2929-2934$.

Wang, C.P., Ding, Y. J., Teppen, B. J., Boyd, S. A., Song, C. Y., Li, H., 2009. Role of Interlayer Hydration in Lincomycin Sorption by Smectite Clays. Environmental Science and Technology 43, 6171-6176.

Watanabe, N., Harter, T.H., Bergamaschi, B.A., 2008. Environmental Occurrence and Shallow Ground Water Detection of the Antibiotic Monensin from Dairy Farms. Journal of. Environmental Quality 37, 78-85.

Watanabe, N., Bergamaschi, B. A., Loftin, K. A., Meyer M. T., Harter T., 2010. Use and environmental occurrence of antibiotics in freestall dairy farms with manure forage fields. Environmental Science and Technology 44, 6591-6600.

Water UK., 2011. Last accessed October 2011.

$<$ http://www.water.org.uk/home/policy/positions/metaldehyde-briefing $>$ 
Wells, M.J.M., 2006. Log Dow: Key to understanding and regulating wastewater-derived contaminants. Environmental Chemistry 3, 439-449.

Wick, L.Y., Remer, R.,Wurz, B., Reichenbach, J., Braun, S., Schäfer, F., Harms, H., 2007. Effect of fungal hyphae on the access of bacteria to phenanthrene in soil.Environmental Science and Technology 41, 500-505.

Williams, G. M., Ross, C. A. M., Stuart, A., Hitchman, S. P and Alexander, L. S., 1984. Controls on contaminant migration at the Villa Farm Lagoons. Quarterly Journal of Engineering Geology and Hydrology 17, 39-55.

Wong, C.S., 2006. Environmental fate processes and biochemical transformations of chiral emerging organic pollutants. Analytical and Bioanalytical Chemistry 386, 544-558.

Worrall, F., 2001. A molecular topology approach to predicting pesticide pollution of groundwater. Environmental Science and Technology 35, 2282-2287.

Worrall, F., Besien, T., 2005. The vulnerability of groundwater to pesticide contamination estimated directly from observations of presence or absence in wells. Journal of Hydrology 303, 92-107.

Worrall, F., Kolpin, D.W., 2004. Aquifer vulnerability to pesticide pollution-combining soil, land-use and aquifer properties with molecular descriptors. Journal of Hydrology 293, 191204. 
Zippel, M., Hannappel, S., Discher, K., Muller, B., 2010. Mathematical transport simulation of pharmaceutical compounds in groundwater during bank filtration. German Federal Environment Agency. (Accessed May 2010) http://www.umweltbundesamt.de/ubainfomedien/ mysql_medien.php?anfrage=Kennummer\&Suchwort=3918

Zuccato, E., Calamari, D., Natangelo, M., Fanelli, R., 2000. Presence of therapeutic drugs in the environment. Lancet 355, 1789-1790.

Zuehlke, S., Duennbier, U., Heberer, T., Fritz, B., 2004. Analysis of endocrine disrupting steroids: Investigation of their release into the environment and their behaviour during bank filtration. Ground Water Monitoring and Remediation 24, 78-85.

\section{Figure captions:}

Figure 1. Schematic diagram, using the source-pathway-receptor approach, highlighting potential sources and pathways for groundwater pollution by EOCs based on reviewed literature (sources: Halling-Sørensen et al. 1994; Heberer et al. 2002; Díaz-Cruz and Barceló. 2008).

Figure 2. Box-plot of maximum EOC concentration in groundwater by major sources; agricultural waste (from waste lagoons and biosolids), landfill, septic tanks, waste water (industrial and municipal). Suspected outliers $(+)$ are $25^{\text {th }}$ and $75^{\text {th }}$ percentile $+/-1.5($ IQR $) . n=$ number of results, $\mathrm{c}=$ number of different compounds for each group. For comparison, the solid horizontal line is the EU drinking water limit for pesticides.

Figure 3. Box-plot of maximum EOC concentration in groundwater by major compound groups; $1=$ steroids and hormones, $2=$ sweeteners and food preservatives, $3=$ industrial 
compounds, $4=$ life-style compounds, $5=$ PPCPs (not including group 6 ), $6=$ veterinary compounds. Note the log scale on the y-axis. Suspected outliers $(+)$ are $25^{\text {th }}$ and $75^{\text {th }}$ percentile $+/-1.5(\mathrm{IQR}) . \mathrm{n}=$ number of results, $\mathrm{c}=$ number of different compounds for each group. For comparison, the solid horizontal line is the EU drinking water limit for pesticides.

Figure 4. Cumulative probability plot of maximum EOCs concentration in groundwater for both reconnaissance and targeted studies. This data was compiled from 74 published studies from 14 countries. Reconnaissance studies $(n=14)$, targeted studies $(n=60)$. It includes data from 180 different individual EOCs as well as degradates. Note the log scale on the $\mathrm{x}$-axis. For comparison, the solid vertical line is the EU drinking water standard for pesticides.

\section{Table captions:}

Table 1. Summary statistics for maximum concentrations $(\mathrm{ng} / \mathrm{L})$ found in groundwater for EOCs and degradates that were detected in at least 4 separate studies, their major use and $\mathrm{K}_{\mathrm{ow}}$

Table 2. Groundwater EOC occurrence in regional, national and pan-national studies.

Table 3. A comparison of detection frequency (\%), max concentrations (ng/L) and number of samples for PPCPs (sulfamethoxazole, ibuprofen and carbamazepine), industrial compounds (nonylphenol and bisphenol A) and caffeine in reconnaissance studies.

\section{Supplementary material:}

Table S1. Summary statistics for maximum detected concentrations and references for selected EOC in groundwater covered in this review. 
